\title{
QUEEN'S
UNIVERSITY
BELFAST
}

\section{Thermokinetic study of residual solid digestate from anaerobic digestion}

Akor, C., Osman Ahmed, A. O., Farrell, C., McCallum, C., Doran, W. J., Morgan, K., Harrison, J., Walsh, P., \& Sheldrake, G. (2021). Thermokinetic study of residual solid digestate from anaerobic digestion. Chemical Engineering Journal, 406, [127039]. https://doi.org/10.1016/j.cej.2020.127039

Published in:

Chemical Engineering Journal

Document Version:

Peer reviewed version

Queen's University Belfast - Research Portal:

Link to publication record in Queen's University Belfast Research Portal

\section{Publisher rights}

Copyright 2020 Elsevier

This manuscript is distributed under a Creative Commons Attribution-NonCommercial-NoDerivs License

(https://creativecommons.org/licenses/by-nc-nd/4.0/), which permits distribution and reproduction for non-commercial purposes, provided the author and source are cited.

\section{General rights}

Copyright for the publications made accessible via the Queen's University Belfast Research Portal is retained by the author(s) and / or other copyright owners and it is a condition of accessing these publications that users recognise and abide by the legal requirements associated with these rights.

Take down policy

The Research Portal is Queen's institutional repository that provides access to Queen's research output. Every effort has been made to ensure that content in the Research Portal does not infringe any person's rights, or applicable UK laws. If you discover content in the Research Portal that you believe breaches copyright or violates any law, please contact openaccess@qub.ac.uk. 
Thermokinetic Study of Residual Solid Digestate from Anaerobic Digestion

Collins I. Akora,b, Ahmed I. Osman ${ }^{a}$, Charlie Farrell ${ }^{c}$, Christopher S. McCallum ${ }^{d}$, W. John Doran $^{d}$, Kevin Morgan ${ }^{a \star}$, John Harrisonc, Pamela J. Walshª and Gary N. Sheldrake ${ }^{a \star}$

a School of Chemistry and Chemical Engineering, Queen's University Belfast, Belfast BT9 5AG, Northern Ireland, UK

b Bryden Centre, Queen's University Belfast, Belfast, BT7 1NN, Northern Ireland, UK

${ }^{c}$ Renewable Engine, Innotech Centre, South West College, Cookstown, Co. Tyrone, BT80 8DN, Northern Ireland, UK.

d Bryden Centre, Letterkenny Institute of Technology, Port Road, Letterkenny, Donegal, F92 FC93, Ireland

*corresponding authors: kmorgan08@qub.ac.uk; g.sheldrake@qub.ac.uk

ABSTRACT: Anaerobic digestion (AD) has become an effective waste management method in the agri-food sector to dispose of livestock and food wastes. As AD becomes more widely used new challenges emerge, such as the disposal of digestate by-products. Currently, the principal method for handling solid digestate (SD) is direct application to land as an organic fertiliser. However, as the sector grows, this option is less viable due to nutrition loading on the land and increased eutrophication. This paper explores the potential of using SD, as a biofuel source. Additionally, the pyrolysis kinetic triplet of residual SD and thermal predictions was reported for the first time using Advanced Kinetics and Technology Solutions (AKTS) thermokinetics software to model and calculate the activation energy $\left(E_{a}\right)$ and other kinetic parameters. ASTM-E698, Ozawa-Flynn-Wall and differential iso-conversional (model-free) methods were used and the $E_{a}$ values calculated from each model were 169.8, $75-175.0$, and $85-190.0 \mathrm{~kJ} \mathrm{~mol}^{-1}$, respectively. The kinetic triplet can be used in the scale-up or designing of reactor systems considering SD as a feedstock. The kinetic prediction of isothermal pyrolysis of SD indicated that a temperature higher than $210{ }^{\circ} \mathrm{C}$ is required for onset of decomposition in the sample. Furthermore, SD has the potential to produce an additional $27.9 \mathrm{MJ}$ per day at a $500 \mathrm{~kW}$ standalone on-farm AD plant. This work has 
highlighted the potential of waste solid digestate as a potential solid biofuel that could add an additional revenue stream to $\mathrm{AD}$ plants and make them more sustainable.

Keywords: Thermokinetics, Residual Digestate, Pyrolysis, Kinetic modelling, Sustainable Energy, Circular Economy

\subsection{INTRODUCTION}

The primary carbon feedstock for producing transportation fuels and a wide range of chemicals are fossil sources such as oil, coal and natural gas [1-3] and global energy demand continues to grow and is expected to increase to 778 EJ by 2035 [4]. The burning of fossil fuels represents a significant and real worldwide environmental and health concern [5]. Recent research has presented clean renewable fuel options with proven technology that reduce emissions to the environment [6-8]. The United Nations sustainable development goal (UN SDGs) No.7 (Affordable and Clean Energy) mandates that sustainable modern clean energy is reliable, affordable and accessible for all, UN SDG no. 12 (Responsible Consumption and Production) also stipulates the reduction of waste through recycling and reuse [9-12]. Waste biomass has the potential to offer a sustainable resource for meeting future energy demands [13-16]. The term 'biomass' comprises organic plant matter; such as those derived from agricultural residues, food wastes, energy crops, grasses, algae, wastes from anaerobic digestion $(A D)$ plants and sewage sludge [17]. Biomass energy, considered to be a form of solar energy trapped in plant matter, is environmentally benign because of its carbon neutrality and low sulphur content compared to fossil derived fuels; hence biomass can be a cleaner fuel for power generation [18-20]. Emissions from biomass fuels can be minimal, especially when $\mathrm{CO}_{2}$ emissions from its usage are sequestered effectively. Also, the seasonal challenges/irregularity in energy supply witnessed with other forms of renewable energy such as solar and wind is avoidable with biomass [21]. Therefore, biomass has the potential of contributing to the future energy demand and meeting the UN SDGs. Various authors have reported different types of biomass such as cotton stalk, sugar cane bagasse, shea meal [22], 
barley straw, miscanthus, waste wood, wheat straw, wood pellets and short rotation coppicing willow [18] for energy generation.

Thermochemical and biochemical processing are the two principal technologies employed for the depolymerisation and conversion of lignocellulosic biomass [23]. This is typically how residual SD has been treated and processed to date. Undertaking physical pretreatment such as milling, grinding, extrusion, ultrasonication etc prior to chemical processing is not inexpensive due to the energy consumption [24]. However, it is an important step to optimise bioconversion, the production of depolymerising enzymes, reduce particle size and increase particle distribution to facilitate the overall transformation of lignocellulosic materials (LM) into biofuels without producing toxic by-products [25]. One mode of mechanical reduction involves milling with a variety of mills to breakdown the lignocellulosic material, reducing the crystallinity of cellulose. A range of mills are frequently used for this purpose including: ball mills, centrifugal mills, colloid mills, hammer mills, extruders, knife mills, attrition mills and vibratory mills [26].

According to Osman et al., [2] and Arenas et al., [27] biochemical conversion of lignocellulosic biomass occurs through the process of fermentation or digestion, whilst the thermochemical route is via combustion, gasification, pyrolysis and liquefaction. As such, there is potential to apply established thermochemical, biochemical and mechanical processes for lignocellulosic biomass in the treatment of residual digestate materials. Thermochemical pyrolysis converts biomass in syngas, bio-oil and char [28]. The fixed carbon content, heating value and combustion processes of biomass can be improved via pyrolysis [18]. Biomass pyrolysis/combustion has been reported most often using thermogravimetric analysis (TGA). Different temperature zones of biomass devolatilisation associated with the individual polymeric fractions of the lignocellulosic biomass can also be determined with TGA. Sher et al., [18] used non-isothermal TGA with different gas environments such as $\mathrm{N}_{2}$, air, $\mathrm{CO}_{2}$ and oxy-fuel to examine and report the thermal and kinetic analysis of six diverse biomass fuels. 
$A D$ is a promising treatment method for biomass, combining energy recovery and waste treatment to produce biogas [29]. Food waste (household and commercial) and livestock waste from the agricultural industry (e.g. poultry litter, cow slurry) are commonly used as feedstocks for $A D$ to produce biogas [30]. The implementation of $A D$ has been a major development in the treatment of waste biomass over the last decade [30]. AD of organic matter involves the chemical transformation of particulate and dissolved organic matter into biogas (approx. $65 \% \mathrm{CH}_{4}, 35 \% \mathrm{CO}_{2}$ and trace gases including $\mathrm{H}_{2} \mathrm{~S}, \mathrm{H}_{2}$ and $\mathrm{N}_{2}$ ) through a consortium of interrelated microbial metabolisms [31].

Energy can be recovered from biomass in the form of biogas/biomethane which is utilised in the combined heat and power (CHP) engines for electricity generation [3]. Miguel et al., [32] reported that in 2014, approximately 2,503 million tonnes of waste was produced from domestic and commercial sources in the European Union (EU). The report further stated that $45-55 \%$ was food waste (FW) [32], which can be converted to energy in an AD plant [33]. However, biogas/biomethane alone cannot guarantee a sustainable industry; as the market becomes saturated the cost of electricity will decrease and so other revenue streams are essential to ensure a viable and sustainable industry.

Currently, AD plants produce high volumes of waste digestate which are underutilised. AD in the UK generates a total 277,000 tonnes of digestate per year, which is composed of solid and liquid fractions [34]. In Northern Ireland (NI) in 2017 there were 103 AD sites, either in construction or already approved [3]. It is reported that there will be capacity to treat 1.4 million tonnes of feedstock annually to generate bio-fuel once construction of $\mathrm{NI} \mathrm{AD} \mathrm{plants} \mathrm{is}$ complete [3]. Thermal utilisation of waste and residual material through $\mathrm{AD}$ can reduce $\mathrm{CO}_{2}$ emissions and help solve waste disposal problems [35]. AD facilitates the recovery of nutrients, lowers landfilling and generates renewable bioenergy [36, 37]. Over the last decade, there has been a doubling [38] in the output of municipal solid waste (MSW), biosolids from 
municipal wastewater treatment plants (WWTP) and both solid and liquid digestate from AD plants. It is well recognised that traditional landfilling and incineration of MSW is fast becoming less viable due to landfill availability, cost and environmental constraints [39], making AD a more attractive and feasible option. AD of sewage sludge (SS) in WWTP can be used to produce electricity supply to the grid [40]. The use of activated sludge (AS) [41] as a biological treatment of MSW requires some modelling kinetics to mitigate the negative effect of heavy metals on the heterotrophic bacterial concentration. electricity generated from energy produced by anaerobic digestion of sewage sludge reduces the electrical power requirements from the main grid network to about $27 \%$ in the proposed wastewater treatment plant. Obernberger [42] reported that low $\mathrm{SO}_{\mathrm{x}}$ emissions is an added advantage in the pyrolysis/combustion of MSW and agricultural residue. This is in part due to the $\mathrm{SO}_{2}$ produced during combustion being captured by the 'alkaline ash' from the biomass, thus, co-firing with biomass can also lower overall $\mathrm{SO}_{2}$ emissions [42].

The EU Wastes Framework Directive (2018) are currently investigating the feasibility of valorising solid digestate (SD) from AD plants into biofuels and other chemicals [43]. Monlau et al., [39] and Moretti et al., [44] reported the valorisation of SD from agricultural waste for energy use through pyrolysis. It was further reported that by-products from this process were not toxic, and that coupling pyrolysis to AD presented the best environmental performances as compared to combustion [39]. This was confirmed by the life cycle analysis of SD pyrolytic valorisation of swine and dairy manure feedstock carried out Fernandez-Lopez et al. [45]. According to Silva [46] and Zakzeski [47], residual SD is recognised as important for the production of renewable energy, chemicals and fuels. The new EU regulatory framework under the Renewable Energy Directive (RED-2) includes a combined renewable energy target for 2030 of $32 \%$, with an upward revision clause by $2023[48,49]$. In Europe, it is reported that a larger percentage (approximately $45.1 \%$ ) of the renewable energy is currently generated from biomass [48], hence the need to further optimise valorising of solid residue from AD to increase energy efficiency of AD. 
In order to make better use of SD waste streams and in the targets outlined above [39],[4345] he kinetics of the pyrolysis process, especially the determination of the kinetic triplet (i.e. rate of reaction, activation energy and pre-exponential factor) is required. The kinetic parameters can be used in the scaling up and designing of reactor systems. Additionally, the parameters can be used in process models to describe how the pyrolysis of SD would behave at scale before being employed at an industrial level.

Arenas et al., [27] reported that analysis of kinetic reactions of biomass feedstocks under pyrolysis provides valuable insight on the decomposition, aiding process optimisation and informing reactor design. Huang et al., [50] reported that such analysis reveals key data regarding reaction mechanisms which can help establish mathematical models to describe processes. He et al., [51], Vyazovkin et al., [52], and Osman et al., [4] described the kinetic modelling of biomass pyrolysis/combustion using model-free (iso-conversional) and modelfitting methods. Iso-conversional methods are suited to estimating complex reaction behaviour in a simple manner, such as those consisting of numerous steps, each with varying rates for which basic kinetic models are unsuitable and might lead to wrong kinetic parameters [51]. The differential iso-conversional method requires a number of heating rate curves to calculate the kinetic parameters with respect to the conversion ( $\alpha$ ), enabling $E_{a}$ to be calculated for each conversion point [4]. Given that the thermal analysis mechanism is understood to be complex; having numerous steps and rates, the differential iso-conversional method is more suitable and frequently used in this setting. The Kissinger method is the only model-free method unable to identify the $E_{a}$ as a function of progressive conversion ( $\alpha$ ), in this method activation energy $\left(E_{a}\right)$ is assumed to be constant therefore it is not an iso-conversional method [4]. Scott et al., [53] and Varhegyi et al., [54] stated that the Distributed Activation Energy Method (DAEM), which is a model-fitting method was a precise, flexible and powerful methodology for the assessment of the devolatilisation of kinetic processes of complex feedstocks such as coal or sewage sludge. However, a major limitation of the DAEM is that it is difficult to estimate kinetic parameters due to complexity of the model. Also, it assumes that reaction proceeds through 
infinite and irreversible number of independent parallel reactions [55, 56]. Kumar et al. [57] reported that the Starink model uses approximation and empirical relation between reaction rate and temperature, hence other iso-conversional models such as Flynn-Wall-Ozawa (FWO) are considered to be better [57].The thermal pyrolysis/combustion of SD is considered an endothermic [39] and non-adiabatic process, as a result heat released can lead to a rapid rise in temperature alongside gas release [2]. Therefore, an understanding of the reaction kinetics and endothermicity of the thermal decomposition of SD is critical to clearly characterise the physiochemical pyrolytic attributes and the consequent limits of its application to energy production.

To date there have been very few kinetic modelling studies for the pyrolysis of digestate [55, 58], although these have only reported limited details of the feedstocks for the AD process. Furthermore, there was no clarity in the report of pre-exponential factor $\left(k_{0}\right)$ and only a single kinetic model was utilised in these previous reports.

In this study, the pyrolysis of dry SD, which contains lignocellulosic material (40, 30 and $29 \%$ of cellulose, hemicellulose and lignin, respectively) $[59,60]$ was investigated using a thermogravimetric analysis/differential scanning calorimetry (TGA/DSC) technique operated in a $\mathrm{N}_{2}$ environment. The original $A D$ feedstocks include grass silage, chicken litter and cattle slurry, as is reported previously [61]. The differential iso-conversional method was used for the calculation of the kinetic parameters from the thermogravimetric (TG) curves and from the simulated differential reaction progress, which was validated using the non-isothermal isoconversional model methods. As such it is anticipated that using this robust kinetic modelling approach (in conjunction with experimental thermal analysis) that the current study will provide more details on the potential to valorise AD waste streams (specifically SD) for energy, thereby supporting the circular economy. 
To best report on the kinetic modelling for the pyrolysis of SD material, the methods and results/discussions sections are separated into both experimental and theoretical subsections as follows:

- Characterisation

- Thermal analysis experiments

- Kinetic modelling using AKTS Thermokinetics

- Thermal predictions based on the model

\subsection{EXPERIMENTAL}

2.1 Solid Digestate Preparation. Digestate samples were collected from AgriAD and AFBI AD plants located in Northern Ireland. The digestate sample $(1 \mathrm{~L})$ was separated into liquid and solid fractions using a centrifuge B 4i model operated at $6000 \mathrm{rpm}$ for 9 minutes. The liquid and solid were then stored in the fridge at $0{ }^{\circ} \mathrm{C}$ overnight before being freeze-dried (Lyotrap freeze dryer operated at $-50{ }^{\circ} \mathrm{C}$ and 0.1 millibar vacuum pressure) to completely evaporate the moisture. The freeze-dried samples were ground to a $1 \mathrm{~mm}$ particle size using a polymix grinder (PX-MFC 90D) for the TGA analysis.

2.2 Heat Treatment of Solid Digestate SD (3 g) was heated in ceramic crucibles in a muffle oven (Carbolite ELF $11 / 6$ laboratory chamber furnace, $6 \mathrm{~L}$ capacity) to $700{ }^{\circ} \mathrm{C}$ at a constant heating rate of $5{ }^{\circ} \mathrm{C} \mathrm{min}^{-1}$ with a dwell time of $6 \mathrm{~h}$, then cooled to room temperature inside the furnace. The resultant biomass is referred to as the SD biochar.

\subsection{Solid Digestate Characterisation}

Powder X-ray diffraction (XRD) was performed on both the SD and SD biochar using a PANalytical X'pert Pro X-ray diffractometer. XRD was used to assess the change in mineral composition in the SD after heat treatment. The diffractometer was fitted with $\mathrm{CuK}_{\alpha} \mathrm{X}$-ray source with a wavelength of $1.5405 \AA$. Diffractograms were collected from $5^{\circ}$ to $90^{\circ}$ with a step 
size of $0.01^{\circ}$. The X-ray tube was operated at $40 \mathrm{kV}$ and $40 \mathrm{~mA}$. The phases were characterised by comparing with diffraction pattern using the automatic search function reference data base in the X'pert software library [62].

Elemental $(\mathrm{C}, \mathrm{H}, \mathrm{N}$, and $\mathrm{S}$ ) analysis was performed using a PerkinElmer PE2400 CHNS/O Elemental Analyser. From the $\mathrm{C}, \mathrm{H}, \mathrm{N}$ and $\mathrm{S}$ percentage composition data acquired, the balance is assumed to be oxygen (i.e. oxygen content was calculated by difference of known total amount of sample and the measured amounts of $\mathrm{C}, \mathrm{H}, \mathrm{N}$ and $\mathrm{S}$ ). ASTM standards were used for the analysis, these include the \% of moisture (ASTM D2867-95), volatile matter (ASTM D5832-95), ash content (ASTM D2866-94) and fixed carbon (by difference) was determined $[62,63]$.

TGA was performed using a simultaneous thermal analysis NETZSCH Jupiter STA 449C (TGA/DSC) thermogravimetric analyser. Samples were heated at a specific temperature range from $20-900{ }^{\circ} \mathrm{C}$ with different ramp rates of $0.5,1.0,4.0$ and $8.0{ }^{\circ} \mathrm{C} \mathrm{min}{ }^{-1}$, under a dry $\mathrm{N}_{2}$ stream at a flow rate of $40 \mathrm{~cm}^{3} \mathrm{~min}^{-1}$. The weights of the samples used for TGA analysis were in the range of 11 to $14.3 \mathrm{mg}$. For quantitative evaluation of weight loss, the TGA instrument was calibrated by running a blank prior to the samples. TGA analysis was run in duplicate.

\subsection{Advanced Kinetics and Technology Solutions (AKTS) Study}

Kinetic modelling is used for the description of kinetic parameters which can be used to help inform industry and the wider audience by providing insight into the reaction and as well explain the thermal behaviour of the material. The modelling in this study predicts the behaviour beyond the experimental TGA (which is considered analogous to pyrolysis) data by making an accurate prediction for an operation involving isothermal heating [64]. AKTS software from Setaram KEP Technologies has been reported in literature for kinetic modelling studies $[65,66]$.The AKTS software follows the recommendation of international confederation 
for thermal analysis and calorimetry (ICTAC) kinetics committee on fundamental principles that underpins the correct calculation of kinetic analysis data.[67]

Herein AKTS Thermokinetics was used in order to determine $E_{a}$ and pre-exponential factor ( $\left.k_{0}\right)$ using the ASTM E-698 method and non-isothermal iso-conversional methods (OzawaFlynn-Wall and differential iso-conversional) in the manner reported previously $[4,68]$. The differential iso-conversional method is known to be more accurate as it avoids assumptions of the reaction formation, while it does not assume that the $k_{0}$ and $E_{a}$ are constant as the reaction progresses [69], unlike the Ozawa-Flynn-Wall and ASTM-E698 methods. The non-isothermal iso-conversional methods, however, can still provide some useful insights and so were still utilised in this work for comparison and validation purposes. Simulations generated from the calculated kinetic parameters also allow for validation via comparison on a point by point basis with the experimental data.

Experimental data from TGA with the 4 different heating rates $\left(0.5,1.0,2.0\right.$ and $\left.4.0{ }^{\circ} \mathrm{C} \mathrm{min}{ }^{-1}\right)$ was imported (in ASCII file format) into the AKTS solid-state kinetic solver. The data was subsequently changed to DTG format, the first derivative of the TGA. Tangential sigmoid baselines were constructed on the DTG plots to integrate the curve and give the evaluation of the kinetic parameters such as rate of reaction, activation energy and pre-exponential constant [64]. This allows for the determination of a temperature dependence which can be used to predict behaviour of the reaction progress at other temperatures. As the digestate pyrolysis reaction progress, there is a change in the specific heat of the reactant-products mixture, thus changing the heat of reaction and as well the kinetic parameters. Specifically, using the AKTS package; the progress/extent of reaction $(\alpha)$ and the reaction rate can be predicted for a wide variety of temperature profiles (non-isothermal, isothermal, modulated or periodic temperature variations or step base heating). The software ultimately provides a robust and accurate result due to strict thermokinetics criteria of average correlation coefficient $\mathrm{R}$ having to be greater than 0.95 and the plotting of high-resolution data over 10,000 specific data points for the parameters and alpha values. 
This allows for the determination of a temperature dependence which can be used to predict behaviour of the reaction progress at other temperatures. The calculated kinetic parameters are used to generate simulations for the reaction progress and reaction rate. These simulations can be compared with the corresponding experimental dataset in order to assess the accuracy of the calculated kinetic parameters at different ramp rates and at different stages of the reaction. The calculated results from the pyrolysis are affected by the heat of the reaction and by the change of the specific heat of the mixture reactant-products as the reaction progresses. The equation for the solver for the reaction progress $A(t)$ are included below in eqn. 1 and 2

$\frac{d A}{d t}=\frac{(S(t)-B(t))}{\int_{t_{0}}^{t e n d}(S(t)-B(t) d t)}$

$A(t)=\frac{\int_{t_{0}}^{t}(S(t)-B(t) d t)}{\int_{t_{0}}^{t} \text { end }(S(t)-B(t) d t)}$

With $0<A(t)<1$ and $B(t)=(1-A(t)) *\left(a_{1}+b_{1}{ }^{*} t\right)+A(t) *\left(a_{2}+b_{2}{ }^{*} t\right)$

Where $\mathrm{B}(\mathrm{t})$ is the baseline, $\mathrm{S}(\mathrm{t})$ is the differential signal, $\frac{d A}{d t}$ is the reaction rate, $\mathrm{a}_{1}+\mathrm{b}_{1}{ }^{*} \mathrm{t}$ is the tangent at the beginning of the signal $\mathrm{S}(\mathrm{t})$ and $\mathrm{a}_{2}+\mathrm{b}_{2}{ }^{*} \mathrm{t}$ is the tangent at the end of the signal $S(t)$.

\subsection{Kinetic Modelling Methods}

\subsubsection{Iso-conversional methods}

Model generation (which is dependent on the best fitting of the TG data with the distinct models using a single TGA/DSC curve) and model-free (iso-conversional) are the two frequently used methods in the study of TGA/DSC solid-state kinetic data $[19,51]$. This is due to the simplicity of the differential iso-conversional method and elimination of error associated with the model fitting method, as the former is advantageous over the latter. The higher accuracy of the differential iso-conversional is attributed to the avoidance of assumptions made of the reaction 
formation, as well as considering that the $k_{0}$ and $E_{a}$ vary as the reaction progresses. The solver evaluates the apparent activation energy and pre-exponential factor at numerous intervals across the entire data signal thereby determining the kinetic parameters as the reaction progresses. The equations in ESI (Eqn. S1 - S5) [4, 70] detailed the fundamental principles of the differential iso-conversional (model-free) method.

\subsubsection{Non-isothermal Methods}

\subsubsection{Non-isothermal non- Iso-conversional Methods}

ASTM-E698 Method [4]: This method is in-between the model fitting and model-free methods. The model-free approximation of the activation energy assessed from the Kissinger's plot is used for calculation [52]. In a single-step reaction, this method is more suitable and further details are given in the ESI.

\subsubsection{Non-isothermal Iso-conversional Methods}

Ozawa-Flynn-Wall Method [71]: This method suggests the calculations of the difference of the apparent activation energy with regards to various linear thermogravimetric curves using the integral iso-conversional analysis method $[68,71]$; hence, it is considered suitable for multiple-step reactions like autocatalytic reactions. $E_{a}$ is calculated as detailed in the ESI.

\subsubsection{Model Fitting}

The accuracy of the calculated kinetic parameters is validated by comparing the experimental data with the simulated reaction progress using an error analysis using a previously reported method [72]. Further details are provided in the ESI.

\subsection{Experimental Overview}

Fig. 1 is a schematic which presents a graphical overview of the experimental methods reported within this manuscript alongside some peripheral items to help to contextualise the current work. The process of energy production is depicted in the schematic occur in two 
phases i.e., biogas production in AD from biomass feedstocks and post AD pyrolysis of SD. The SD was pyrolysed using a TGA and experimental data extracted as described in section 2.4 and modelled with AKTS software. Kinetic parameters were determined using the OzawaFlynn-Wall, differential iso-conversional and ASTM-E698 thermokinetics models. Furthermore, characterisation was conducted using CHNS elemental analysis for SD and $\mathrm{XRD}$ of SD and its biochar. Finally, the isothermal kinetic predictions for pyrolysis of SD at a range of temperatures was completed with the AKTS software.

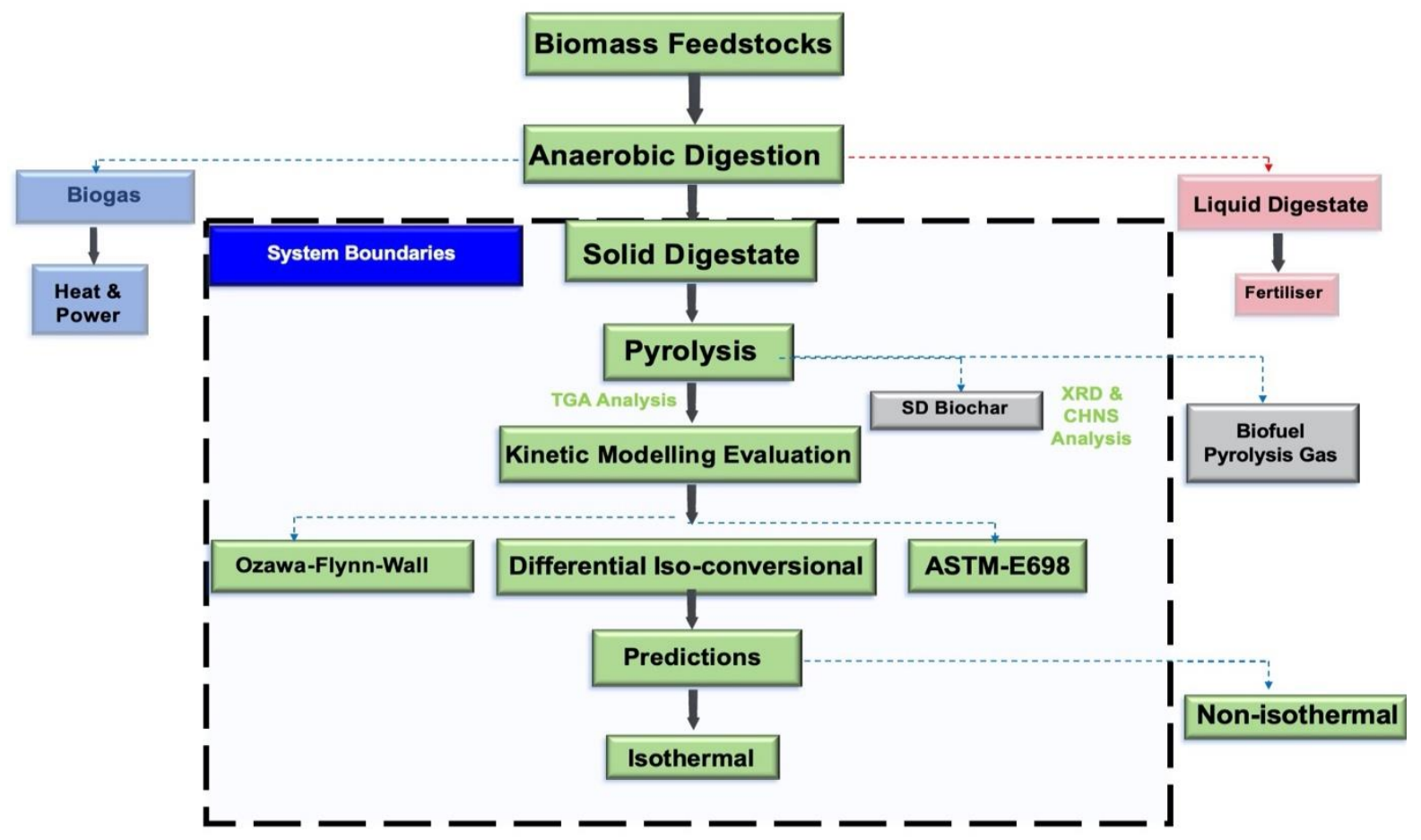

Fig. 1. Flowchart of research methodology

\subsection{RESULTS AND DISCUSSION}

\subsection{Biomass Ultimate and Proximate Analysis}

Biofuels produced from biomass tend to be more reactive than conventional fuels from fossil sources and as well contain higher volatile yields and lower fixed carbon, hence the understanding of its elemental components is important for the analysis of the heating values $[73,74]$. From the data reported in Table 1, both sewage sludge (SS) and bituminous coal 
(BC) have a higher content of $\mathrm{C}, \mathrm{H}, \mathrm{N}$ and $\mathrm{S}$. The oxygen in the solid digestate $(57.5 \%)$ is higher than in sludge (32.1\%) and coal (7.7\%). Also, the moisture content of the solid digestate is higher (12.3\%) than that of sludge and coal (6.9 and $4.9 \%$, respectively) [63]. The lower oxygen content for sludge and coal could presumably give rise to a higher energy output per gram when combusted. This also correlates with the higher moisture content in the digestates. Fixed carbon (FC) represents the portion of the coal that must be burned in a solid state and its knowledge aids in equipment selection for combustion/pyrolysis. FC reveals the caking properties (e.g. moisture, ash) of coal and biomass as a fuel [75]. The FC content of the SD is lower $(6.6 \%)$ compared to the sewage sludge and coal (7.0 and 48.1 , respectively). In summary, these parameters would all indicate that combustion of SD may not be beneficial due to potentially lower calorific values while the higher oxygen content would create further issues with higher soot production than coal or sludge [76]. The volatile matter content of the SD is relatively high (62.0\%) compared to sewage sludge and coal (44.6 and $32.3 \%$, respectively). While the sewage sludge volatile content is still higher than that of coal, it has a higher $\mathrm{N}$ content compared to the SD (6.3\% versus $2.3 \%)$. This is expected due to the high ammonia content in the sludge [77]. This means that sewage sludge is not ideal for combustion (higher NOx emissions) while the ammonia content may give rise to issues in other processes such as pyrolysis (e.g. corrosion) [78].

Furthermore, using the method by Channiwala [79], the gross energy (higher heating value, $\mathrm{HHV}$ ) and net calorific value (lower heating value, LHV) of SD was calculated from the elemental analysis in Table 1 as 11.72 and $9.90 \mathrm{~kJ} \mathrm{~kg}^{-1}$, respectively. As such, ultimate and proximate analysis indicates the potential use of SD as feedstock in pyrolysis processes for bio-oil production [27].

Table 1. Ultimate and Proximate analysis of sewage sludge [80], bituminous coal [73] and residual digestate 


\begin{tabular}{|c|c|c|c|c|c|c|c|c|c|c|c|}
\hline \multirow{2}{*}{ FUEL } & \multicolumn{5}{|c|}{ ULTIMATE ANALYSIS (\%) } & \multicolumn{5}{|c|}{ PROXIMATE ANALYSIS (\%) } & \multirow{2}{*}{ Reference } \\
\hline & C & H & 0 & $\mathbf{N}$ & $\mathbf{S}$ & Moisture & Volatile & FC & Ash & $\begin{array}{c}\mathrm{HHV} \\
\mathrm{kJ} \mathrm{kg}^{-1}\end{array}$ & \\
\hline Sewage Sludge & 52 & 6.3 & 32.1 & 6.3 & 3.1 & 6.9 & 44.6 & 7 & 41.5 & 21.6 & [80] \\
\hline Bituminous Coal & 65.7 & 5.6 & 7.7 & 1.2 & 0.5 & 4.9 & 32.3 & 48.1 & 14.7 & 28.5 & [73] \\
\hline Solid Digestate & 34.9 & 5 & 57.5 & 2.3 & 0.3 & 12.3 & 62 & 6.6 & 19.1 & 11.7 & This work \\
\hline
\end{tabular}

\subsection{1 van Krevelen diagram}

Solid fuels are characterised by their degree of carbonisation. The van Krevelen diagram of SS, BC and SD which helps to determine the degree of carbonisation of the reported fuels is shown in Fig. 2. This diagram also aids to better understand the development path of organic matter and the distinct regions of similarity of the solid fuels. As shown in Fig. 2, SD in this study is located in the region known for biomass [18]. SS has an $\mathrm{O} / \mathrm{C}$ ratio of 0.62 and $\mathrm{H} / \mathrm{C}$ of 0.12 placing, $\mathrm{BC}$ has an $\mathrm{O} / \mathrm{C}$ ratio of 0.12 and $\mathrm{H} / \mathrm{C}$ of 0.09 . SD by comparison has an $\mathrm{O} / \mathrm{C}$ of 1.42 and $\mathrm{H} / \mathrm{C}$ of 0.14 . As reported by Sher et al. [18], biofuels have a higher proportion of $\mathrm{O} / \mathrm{H}$ and falls in the category limits of $0.7 \leq \mathrm{O} / \mathrm{H} \leq 1.3$ and $0.075 \leq \mathrm{H} / \mathrm{C} \leq 0.25$, whilst coal fuel ranges from $0 \leq H / C \leq 0.1$ and $0 \leq O / C \leq 0.3$. As defined by Sher the $S D$ is located within the "biofuel" range and is at the upper limit of the O/C content. A possible reason for the higher oxygen content is within the AD process cellulose, and therefore glucose molecules, are consumed as part of the process. This results in lignin and hemicellulose remaining post AD. Lignin contains a higher ratio of oxygen to carbon in comparison to cellulose and therefore would lead to an increase in the O/C ratio remaining post $A D$.

Calculated HHV for SS, BC and SD were $21.60,28.46$ and $11.72 \mathrm{~kJ} \mathrm{~kg}^{-1}$ respectively and LHV were $19.84,27.09$ and $9.90 \mathrm{~kJ} \mathrm{~kg}^{-1}$, respectively. Biofuels with high $\mathrm{H} / \mathrm{C}$ and $\mathrm{O} / \mathrm{C}$ ratios have a low calorific values compared to fossil fuels like coal with lower $\mathrm{H} / \mathrm{C}$ and $\mathrm{O} / \mathrm{C}[25,81]$. This explains why $\mathrm{BC}$ with a lower $\mathrm{H} / \mathrm{C}$ and $\mathrm{O} / \mathrm{C}$ has a high heating values than SS and SD. 


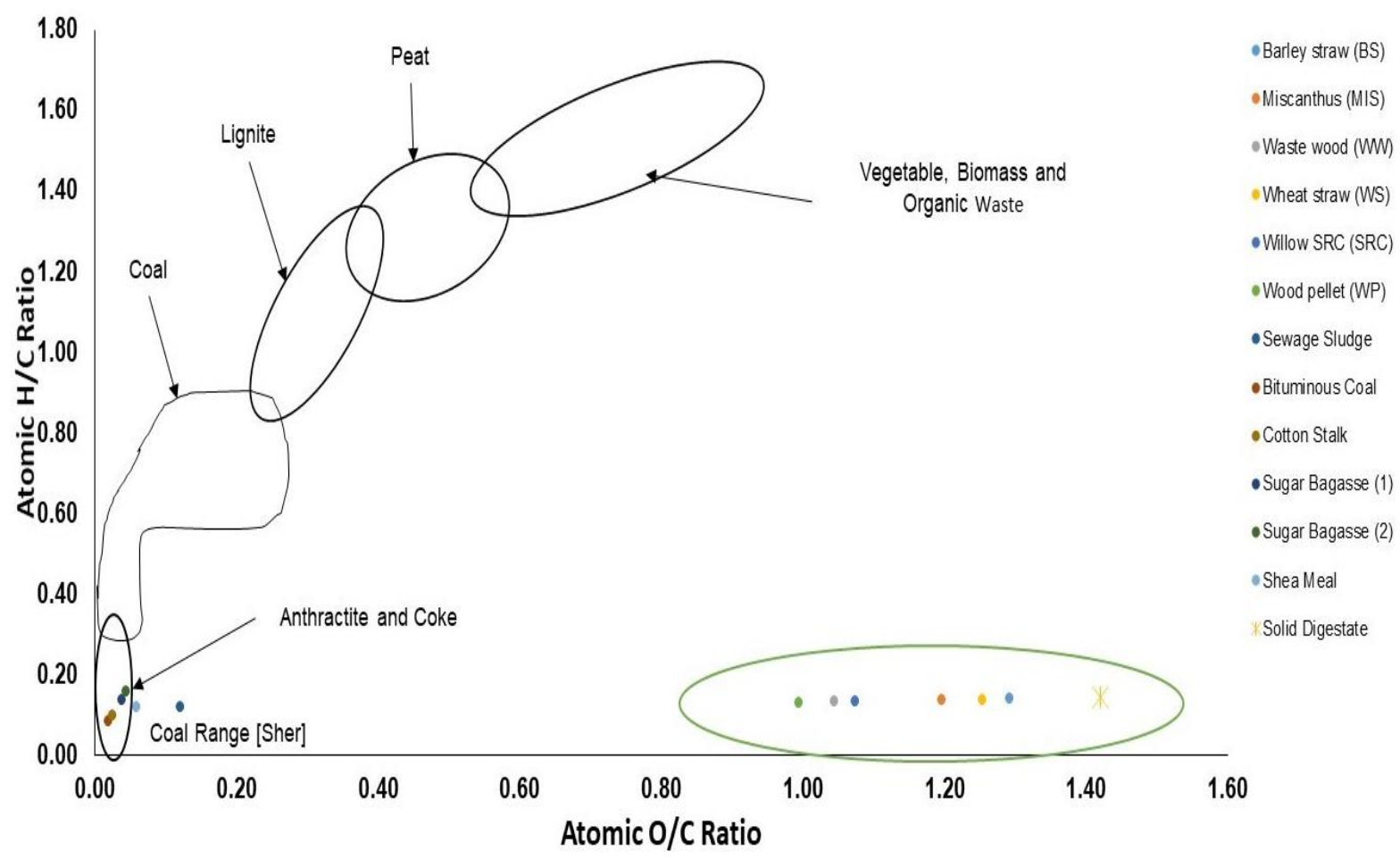

Fig. 2. van Krevelen showing solid fuels characterisation by $\mathrm{H} / \mathrm{C}$ and $\mathrm{O} / \mathrm{C}$ atomic ratios

\subsection{Solid Digestate characterisation.}

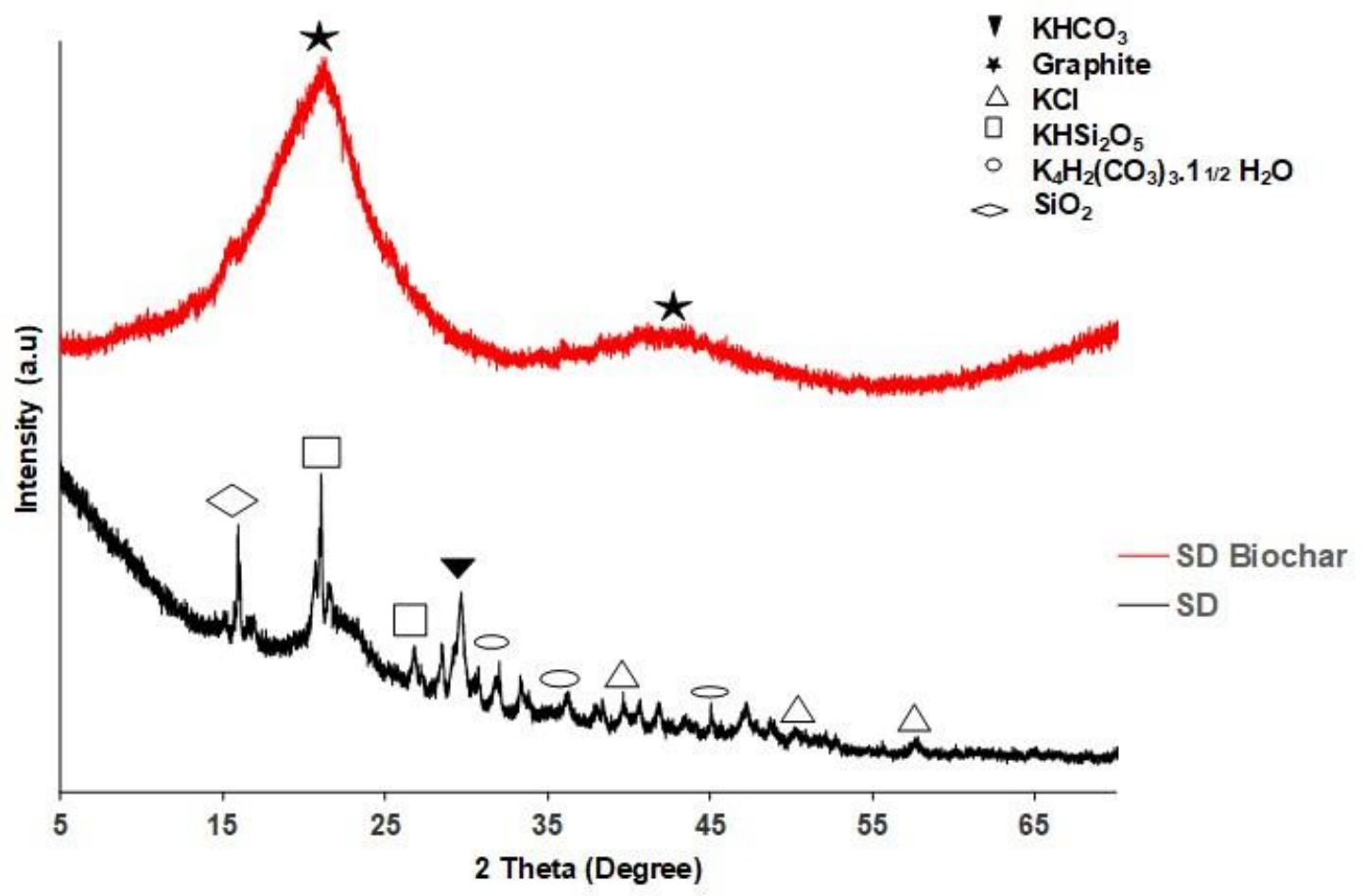


Fig. 3. XRD pattern of Solid digestate before heat treatment and after heat treatment (biochar)

The XRD results for the SD before and after heat treatment (biochar) are reported in Fig. 3. SD sample was heated at $700{ }^{\circ} \mathrm{C}$ and the purpose is to ensure all minerals and volatiles contained in the SD is burned off to obtain the biochar. Temperature ranging from $500-800$ ${ }^{\circ} \mathrm{C}$ was used but $700{ }^{\circ} \mathrm{C}$ was the optimum and gave the desired result by the $\mathrm{XRD}$ characterisation indicating the peak assigned as graphite. The effect of heat treatment on the inorganic fraction of minerals found in the digestate (e.g. $\mathrm{SiO}_{2}, \mathrm{KCl}$ ) was examined using XRD. For SD, prominent peaks were observed where $2 \theta$ equals $15.9,21.5$ and $29.8^{\circ}$, which were assigned to $\mathrm{SiO}_{2}$, (JCPDS No. 03-0226) [82], $\mathrm{KHSi}_{2} \mathrm{O}_{5}$ (JCPDS No. 19-968) [82] and $\mathrm{KHCO}_{3}$ (JCPDS No. 03-0289) [83], respectively. Other less significant peaks were also observed at $2 \theta$ of 40.6 and $50.2^{\circ}$ (JCPDS No: 01-073-0380) which were assigned to $\mathrm{KCl}[84,85]$ and along with other phases including $\mathrm{K}_{4} \mathrm{H}_{2}\left(\mathrm{CO}_{3}\right)_{3 .} 1_{1 / 2}^{1 / 2} \mathrm{H}_{2} \mathrm{O}\left(2 \theta=30.8,36.8\right.$ and $\left.45.03^{\circ}\right)$ [83, 86]. Heating the $\mathrm{SD}$ at $700^{\circ} \mathrm{C}$ removed these mineral fractions as can be observed in the diffractogram of biochar. After heat treatment one prominent amorphous peak formed at $22.1^{\circ}$ which was assigned to graphite.

Fig. 4 reports the devolatilisation process starting at $110-120^{\circ} \mathrm{C}$, with water loss as the SD contains approximately $12.3 \%$ moisture content, and hydrolysis of certain extractives such as esters and fats [87] because of their instability and start to degrade at lower temperature as a result of how highly volatile they are; the devolatilisation of SD biomass commenced at 200 ${ }^{\circ} \mathrm{C}$ and achieves maximum weight lost in the range $200-290{ }^{\circ} \mathrm{C}$. There was a sharp change in gradient with a point of inflection at $300^{\circ} \mathrm{C}$. Above $350^{\circ} \mathrm{C}$, a sudden change in the slope of the TGA curve occurs which leads to a moderate weight loss in the temperature range of 370 $-500{ }^{\circ} \mathrm{C}$. At a higher temperature, decomposition of the strongest bonds in lignin take place up to $630^{\circ} \mathrm{C}$. This agrees with reports from other literature sources [27, 88, 89]. Generally, the pyrolysis of SD occurred in three stages/zones at varying temperatures were drying (water evaporation at $110-120^{\circ} \mathrm{C}$ ), devolatilisation of hemicellulose and cellulose at $200-350{ }^{\circ} \mathrm{C}$, and Lignin decomposition/breakdown (combustion zone) at $350-650^{\circ} \mathrm{C}[58,90]$. During the 
devolatilisation zone $\left(200-350^{\circ} \mathrm{C}\right), \sim 40 \%$ weight loss was observed. At the end, from 650 ${ }^{\circ} \mathrm{C}$ the slow decomposition over the remaining temperature down to $800^{\circ} \mathrm{C}$ produced pyrolysis residue (ash) which is often referred to long tailing section [18, 21, 22].

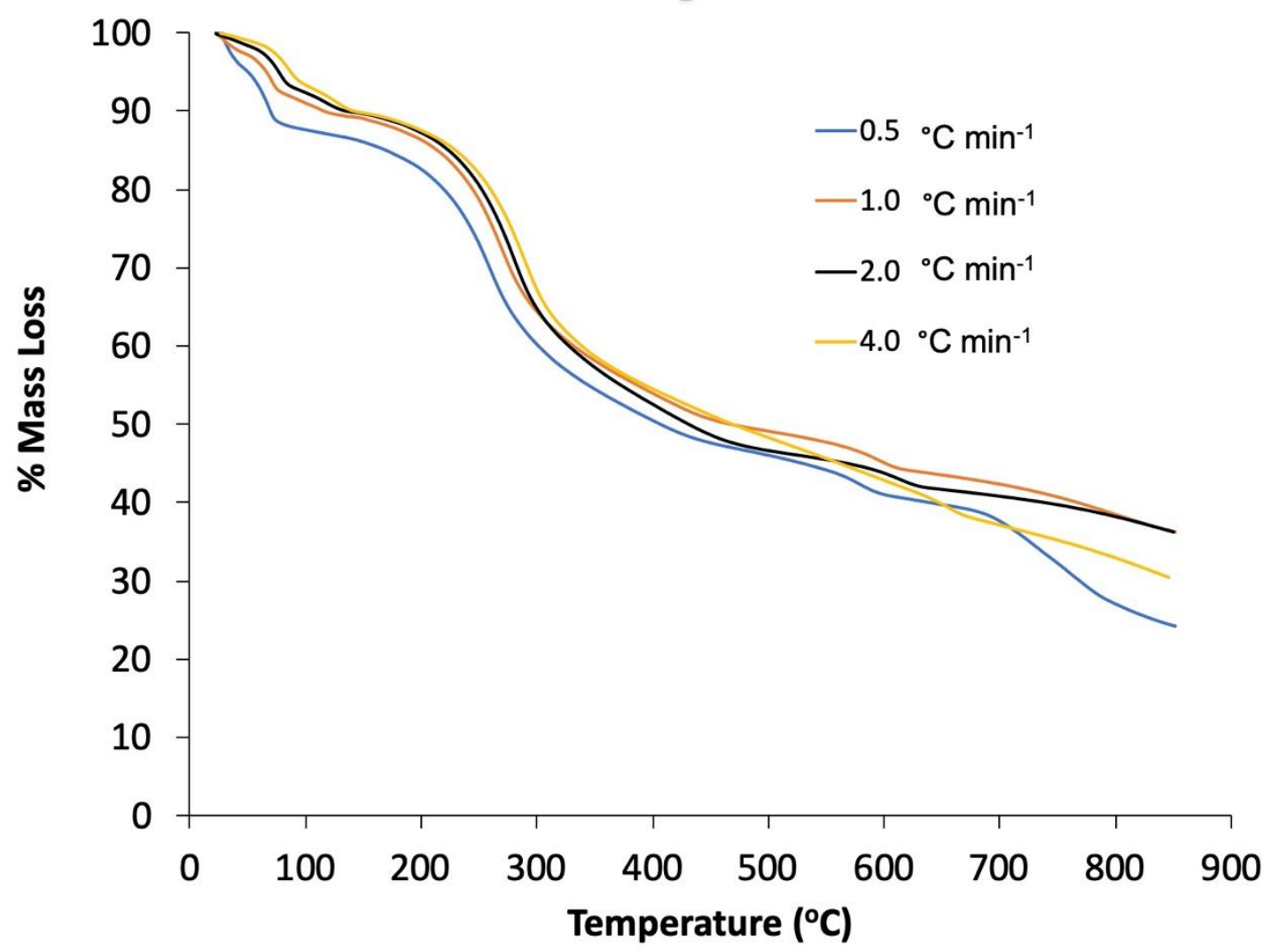

Fig. 4. TGA curves of solid digestate at different heating rates: $0.5,1.0,2.0$, and $4.0{ }^{\circ} \mathrm{C} \min ^{-1}$ under a nitrogen atmosphere

\subsection{Kinetic Models Discussion}

The TGA under nitrogen flow is analogous to the pyrolysis of SD from which the activation energy and the kinetic parameters were calculated from the TGA curves at various heating rates $\left(0.5,1.0,2.0\right.$ and $\left.4.0^{\circ} \mathrm{C} \mathrm{min}-1\right)$. The TGA experiments for each of the heating rates were repeated twice and the results were reproducible and within experimental error of $\pm 3 \%$ (see Fig. S2 - S9 in ESI).

TGA detects the mass loss at numerous temperatures as the reaction progresses during the experiments [91]. TGA/DTG results for the mass loss during the pyrolysis of SD under a 
nitrogen atmosphere with different heating rates are reported in Fig. S1. Table 2 reports further details of the pyrolysis. It was evident that as the heating rate increases from $0.5^{\circ} \mathrm{C} \mathrm{min}{ }^{-1}$ to $4.0^{\circ} \mathrm{C} \mathrm{min}-1$, the temperature range of the decomposition increased correspondingly. The time taken for the thermal decomposition decreased significantly with increasing heating rates from $20 \mathrm{~h}\left(0.5^{\circ} \mathrm{C} \mathrm{min}-1\right)$ to $2.7 \mathrm{~h}\left(4.0^{\circ} \mathrm{C} \mathrm{min}^{-1}\right)$. This is expected because as the heating rate increases, the decomposition is faster and takes less time. Williams and Besler [92] stated that as heating rate becomes high, char formation reduces in yields, whilst gas and oil yield increases, and the aqueous phase is independent of the heating rate and remains constant. As the reaction is endothermic, there is a high rate of devolatilisation and reduced residence/retention time in the reactor; hence the reduction in char formation [93]. Also, the peak height increased to about eight times as the heating rate increases from 0.5 to $4.0{ }^{\circ} \mathrm{C}$ $\min ^{-1}$ whilst the peak maximum was shifted towards a higher decomposition temperature by $27.1^{\circ} \mathrm{C}$ [92]. At a heating rate of $0.5^{\circ} \mathrm{C} \mathrm{min}^{-1}$, peak maximum was $261.8^{\circ} \mathrm{C}$ at 476.7 mins and as the heating rate increased to $4.0^{\circ} \mathrm{C} \mathrm{min}{ }^{-1}$, the peak maximum temperature also increased to $288.9^{\circ} \mathrm{C}$ at 65.5 mins. This is reported in the thermal decomposition data in Table 2, which was derived from the DTG curves reported in the ESI (Fig. S1).

Table 2. Thermogravimetric analysis of solid digestate at heating rates in the range of 0.5 to $4{ }^{\circ} \mathrm{C} . \mathrm{min}^{-1}$

\begin{tabular}{|c|c|c|c|c|c|c|}
\hline $\begin{array}{c}\text { HEATING RATE } \\
\left({ }^{\circ} \mathbf{C} \text { MIN }^{-1}\right)\end{array}$ & $\begin{array}{c}\text { TEMPERATURE } \\
\left.\text { RANGE ( }{ }^{\circ} \mathbf{C}\right)\end{array}$ & $\begin{array}{c}\text { TIME RANGE } \\
(\mathbf{M I N})\end{array}$ & $\begin{array}{c}\text { PEAK MAXIMUM } \\
\left.\text { TEMPERATURE ( }{ }^{\circ} \mathbf{C}\right)\end{array}$ & $\begin{array}{c}\text { PEAK MAXIMUM } \\
\text { TIME (MINS) }\end{array}$ & $\begin{array}{c}\text { PEAK HEIGHT } \\
\left(\% \mathbf{M I N}^{-1}\right)\end{array}$ & $\begin{array}{c}\text { Mass Loss } \\
(\%)\end{array}$ \\
\hline $\mathbf{0 . 5}$ & $104-629$ & $160-1200$ & 261.8 & 477 & -0.17 \\
$\mathbf{1}$ & $147-628$ & $123-605$ & 267.9 & 245 & -0.34 \\
$\mathbf{2}$ & $156-676$ & $67-327$ & 279.1 & 128 & -0.81 \\
$\mathbf{4}$ & $155-695$ & $32-167$ & 288.9 & 66 & -1.42 \\
\hline
\end{tabular}




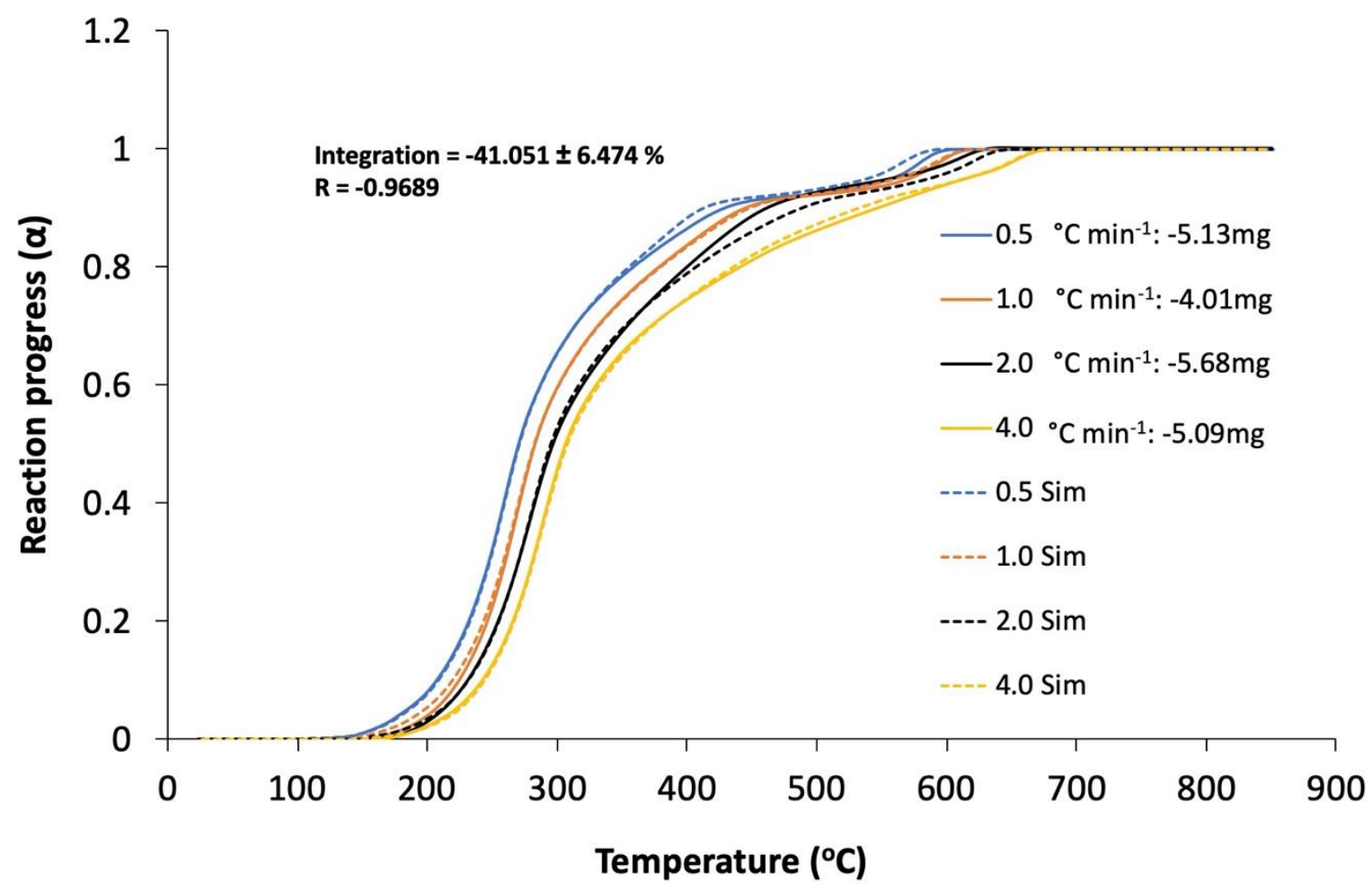

Fig. 5. Experimental (solid lines) and simulated reaction progress (dashed lines) versus the temperature for the solid digestate at different heating rates

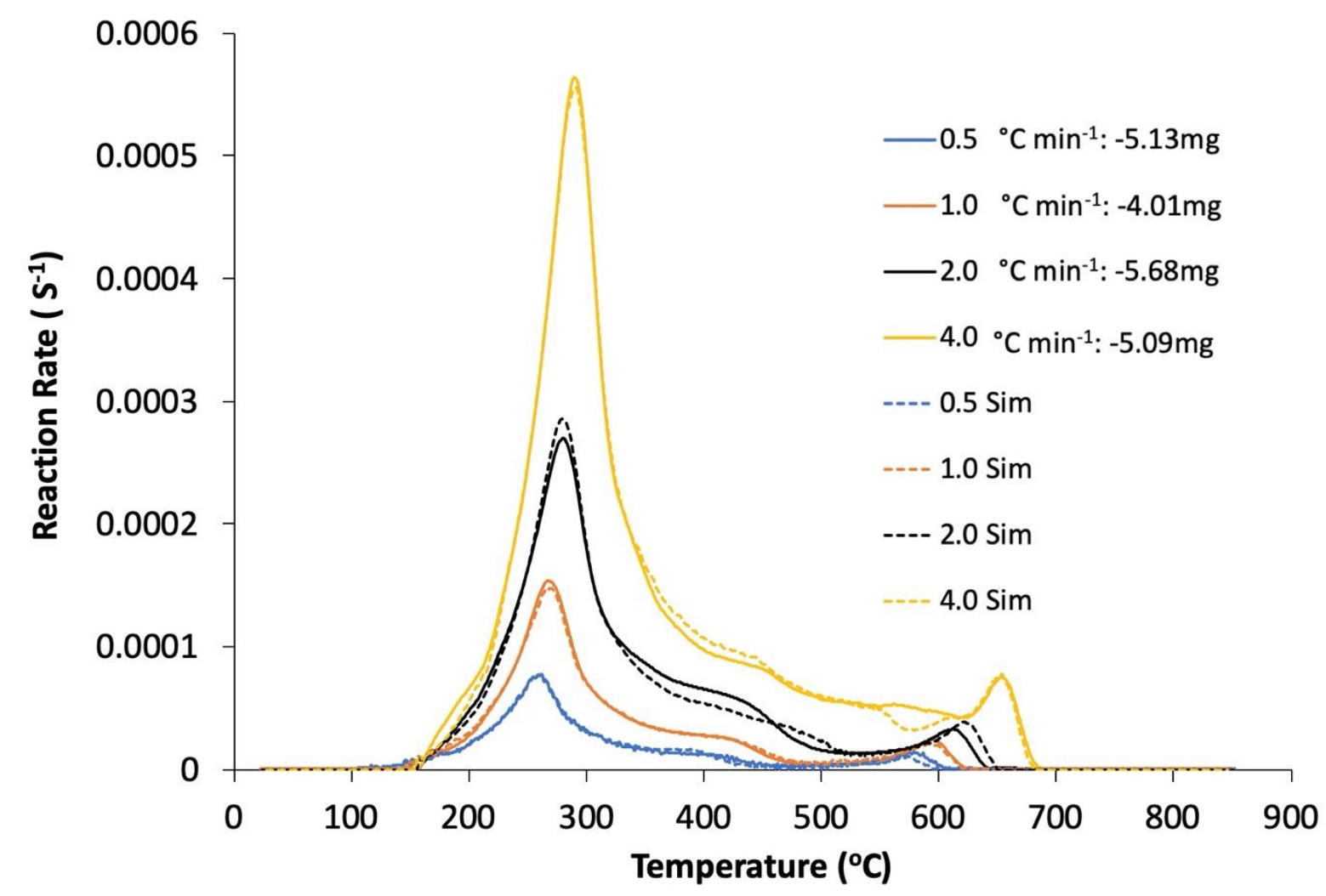


Fig. 6. Experimental (solid lines) and simulated (dashed lines) reaction rate versus the temperature for the solid digestate at different heating rates

The decompositions of hemicellulose and cellulose occur in the range of $200-350{ }^{\circ} \mathrm{C}$, whereas lignin decomposes in the temperature range of $300-600{ }^{\circ} \mathrm{C}$, dependent on the substrate [58]. This is the rate-determining step during the pyrolysis/combustion of the SD biomass [94]. As stated earlier, the reaction mechanism is complicated and difficult to describe using the model-fitting method, as the reactions overlap during the pyrolysis/combustion process. Hence, it is not practicable to detect the kinetic parameters of SD using model-fitting methods. The three stages of weight loss of biomass decomposition in TGA analysis are; dehydration, devolatilisation (active pyrolysis) and char oxidation (passive pyrolysis) [90]. In terms of validating the calculated kinetic parameters, there is an excellent correlation between the experimental data and the simulation based on calculated data for all the heating rates, except for $2{ }^{\circ} \mathrm{C} \mathrm{min}^{-1}$, where there is a slight variation in the temperature range $400-500{ }^{\circ} \mathrm{C}$ as reported in Fig. 5. The shapes of the reaction progress versus temperature curves of each of the heating rates are consistent with each other, with only a slight variation for the heating rate of $2^{\circ} \mathrm{C} \min ^{-1}\left(350-500{ }^{\circ} \mathrm{C}\right)$ and $4^{\circ} \mathrm{C} \min ^{-1}\left(550-600^{\circ} \mathrm{C}\right)$. Furthermore, the critical error obtained from the reaction progress, a measure of the variation between experimental and simulation, for the heating rate of $2{ }^{\circ} \mathrm{C} \mathrm{min}-1$ is $0.96 \%$. This indicates that there is a high level of accuracy in the kinetic parameters calculated and in the subsequent prediction of the behaviour of the reaction progress.

From the comparison of simulation with experimental data in Fig. 5, the critical error for the heating rates for $0.5,1.0,2,0$ and $4.0^{\circ} \mathrm{C} \mathrm{min}{ }^{-1}$ were $0.60,0.52,0.96$ and $0.47 \%$, respectively, which indicates a high-quality fit. The respective error analysis plots are reported in the ESI in Fig. S2 - S5. Overall, the excellent correlations between experimental and simulated data support the validity of the kinetic parameters calculated with the AKTS software. The slight variations between the experimental and simulations in Fig. 5 are also confirmed in Fig. 6 , which reports the reaction rate versus the temperature curves. There was a slight overlap of 
the peak at $290{ }^{\circ} \mathrm{C}$, the inflection at $340-510^{\circ} \mathrm{C}$ and $620-630{ }^{\circ} \mathrm{C}$ for the $2{ }^{\circ} \mathrm{C} \mathrm{min}{ }^{-1}$ heating rate. Also, for $4{ }^{\circ} \mathrm{C} \mathrm{min}-1$ there was an inflection and peak overlap at $\left(350-450{ }^{\circ} \mathrm{C}\right.$, and 560 $-610^{\circ} \mathrm{C}$ ), respectively. The critical error obtained for the reaction rate (Fig. 6), which measures variation between experimental and simulation, for the heating rates for $0.5,1.0$, 2.0 and $4.0^{\circ} \mathrm{C} \mathrm{min}^{-1}$, were $0.49,3.16,0.43$ and $0.38 \%$, respectively; indicating a high-quality fit. The corresponding error analysis plots are reported in the ESI in Fig. S6 - S9.

The kinetic parameters were calculated by the differential iso-conversional method and are reported in Fig. 7 and 8 . The natural logarithm of the reaction rate in $\left(\mathrm{s}^{-1}\right)$ versus the temperature inverse $\left(\mathrm{T}^{-1}\right)$ for the different heating ramp rates is reported in Fig. 7 . By interpreting this data, the differential iso-conversional method in AKTS determines the Arrhenius dependence, thereby giving details on the apparent $E_{a}$ and the $k_{0}$ at each stage of the reaction progress.

In Fig. 8, initially the calculated $E_{a}$ was $\sim 85 \mathrm{~kJ} \mathrm{~mol}^{-1}$ at which point the reaction progress was still zero $(\alpha=0)$, while the pre-exponential factor $\ln \left(A(\alpha) f(\alpha)\right.$ is $\sim 12 \mathrm{~s}^{-1}$. The high activation energy at the beginning of the reaction is ascribed to the carbohydrate polymer (cellulose and hemicellulose) [95]. High energy is required during pyrolysis to break the strong bonds of the lignin, which enclose the cellulose within a lignin-hemicellulose matrix [96]. Activation energy continues to increase reaching an initial peak of $\sim 140 \mathrm{~kJ} \mathrm{~mol}^{-1}$ at $\alpha=0.3$. As the lignin component breaks down at a temperature range of $300-600{ }^{\circ} \mathrm{C}, E_{a}$ decreases to $\sim 60 \mathrm{~kJ}$ $\mathrm{mol}^{-1}$ at $\alpha=0.87$ before increasing again to $\sim 190 \mathrm{~kJ} \mathrm{~mol}^{-1}$ at $\alpha>0.9$. The explanation for this increase can be attributed to the complexity in reaction mechanism of SD pyrolysis or autocatalytic reactions with the decomposition of lignin and formation of ash. This ash contains minerals with catalytic properties with the tendency to melt and sinter due to high reaction temperatures. The sintering can cause some fused deposits, hence the increase in $E_{a}$ as the reaction comes to completion $[4,18,97]$. In general, the $E_{a}$ calculated using the differential iso-conversional method was in the range of $85-190 \mathrm{~kJ} \mathrm{~mol}^{-1}$. 
The suggested mechanism equation [2] from previous studies will be:

(a) Biomass. $\mathrm{H}_{2} \mathrm{O}=$ Biomass $+\mathrm{H}_{2} \mathrm{O}$

(b) Biomass $=$ Y-Char + Pyrolysis Gas

(c) Hemicellulose $=$ Hpy-Char + Hpy-Gas

(d) Cellulose $=$ Cpy-Char + Cpy-Gas

(e) Lignin $=$ Lpy-Char + Lpy-Gas

Where Hpy-Char, Cpy-Char, and Lpy-Char and Hpy-Gas, Cpy-Gas, and Lpy-Gas are the chars and gas produced during the pyrolysis of hemicellulose, cellulose, and lignin, respectively.

However, a single value of $E_{a}$ is not sufficient to robustly define the thermal decomposition of SD because of the complexity of the reaction. Therefore, other methods such as Ozawa-FlynnWall and ASTM-E698 have been used to validate the results $[4,27,52]$. The calculated $E_{a}$ of SD using the ASTM-E698 is $169.8 \mathrm{~kJ} \mathrm{~mol}^{-1}$ as reported in ESI, (Fig. S10). The ASTM method reports a single constant value as it assumes that the kinetic parameters, including the $E_{a}$, remains constant as the reaction progresses. Fig. $9 a, 9 b$ and $9 c$ report the calculated Arrhenius plots, $E_{a}$, and correlation coefficient from the Ozawa-Flynn-Wall method, respectively. From this method, the variation in the $E_{a}$ during the reaction progress was between $75-175 \mathrm{~kJ} \mathrm{~mol}^{-1}$ as reported in Fig. 9b. This was observed as the reaction progressed and nears completion between $0.9-0.98$. The Ozawa-Flynn-Wall method is more accurate than the ASTM-E698 method as it considers that the kinetic parameters, including the $E_{a}$, vary as the reaction progresses, though it is less accurate than the differential isoconversional method due to systematic errors dependent on the small ranges of reaction progress that are integrated [64]. 


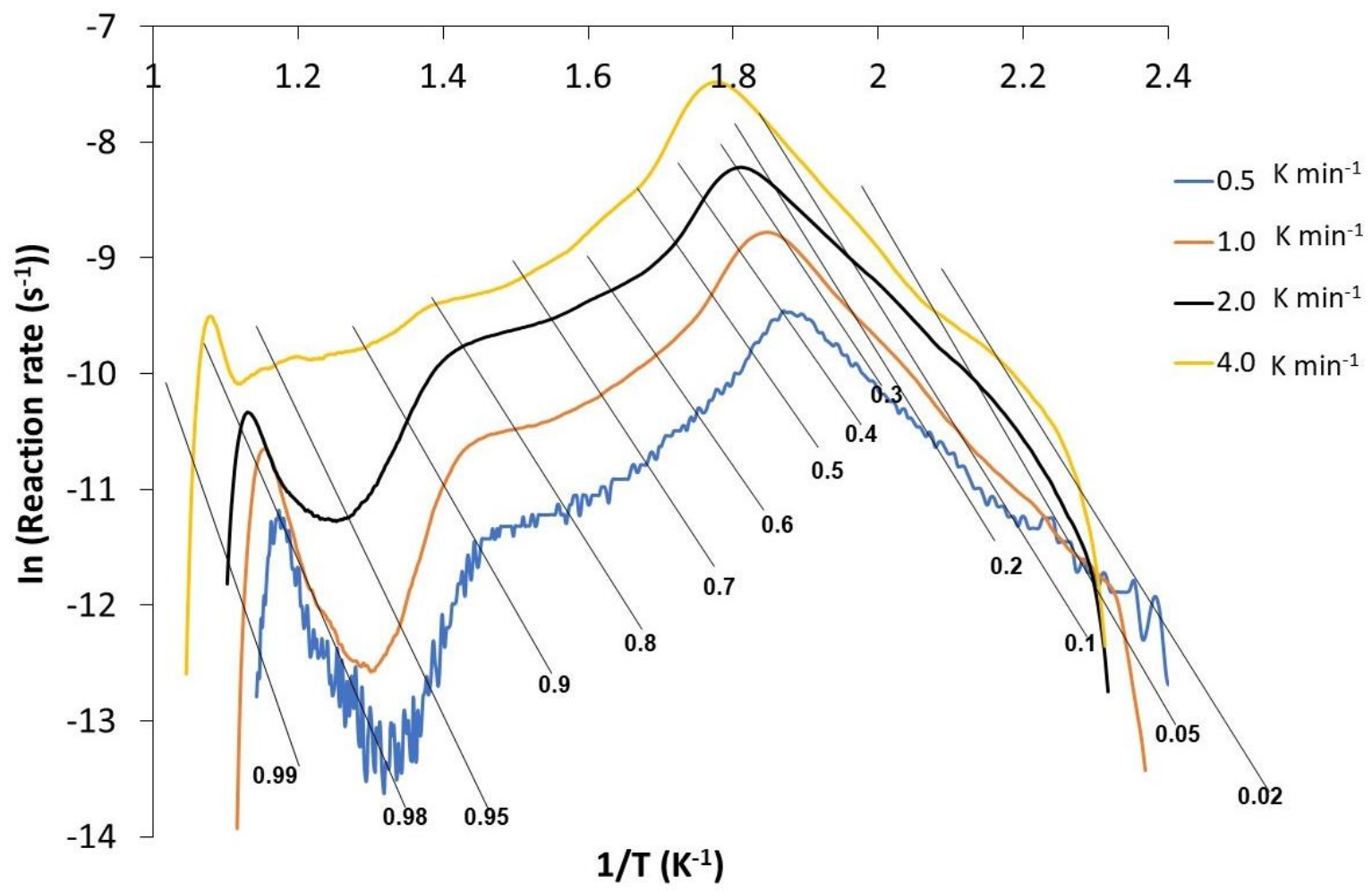

Fig. 7. Natural logarithm of the reaction rate $\left(\mathrm{s}^{-1}\right)$ versus the inverse temperature $\left(\mathrm{T}^{-1}\right)$ using the differential iso-conversional method

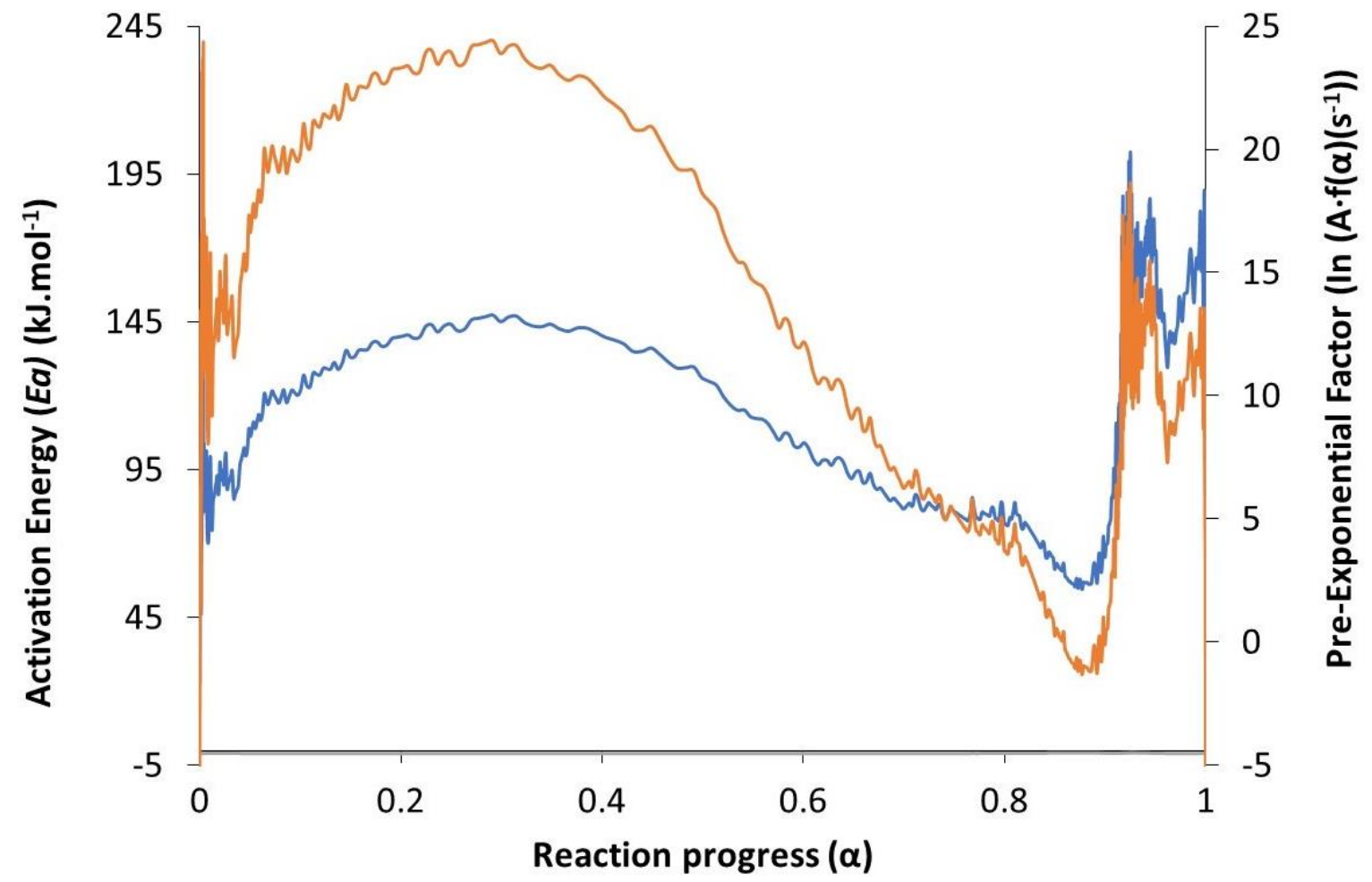

Fig. 8. The activation energy (blue) and pre-exponential factor (orange) calculated with the differential iso-conversional method 


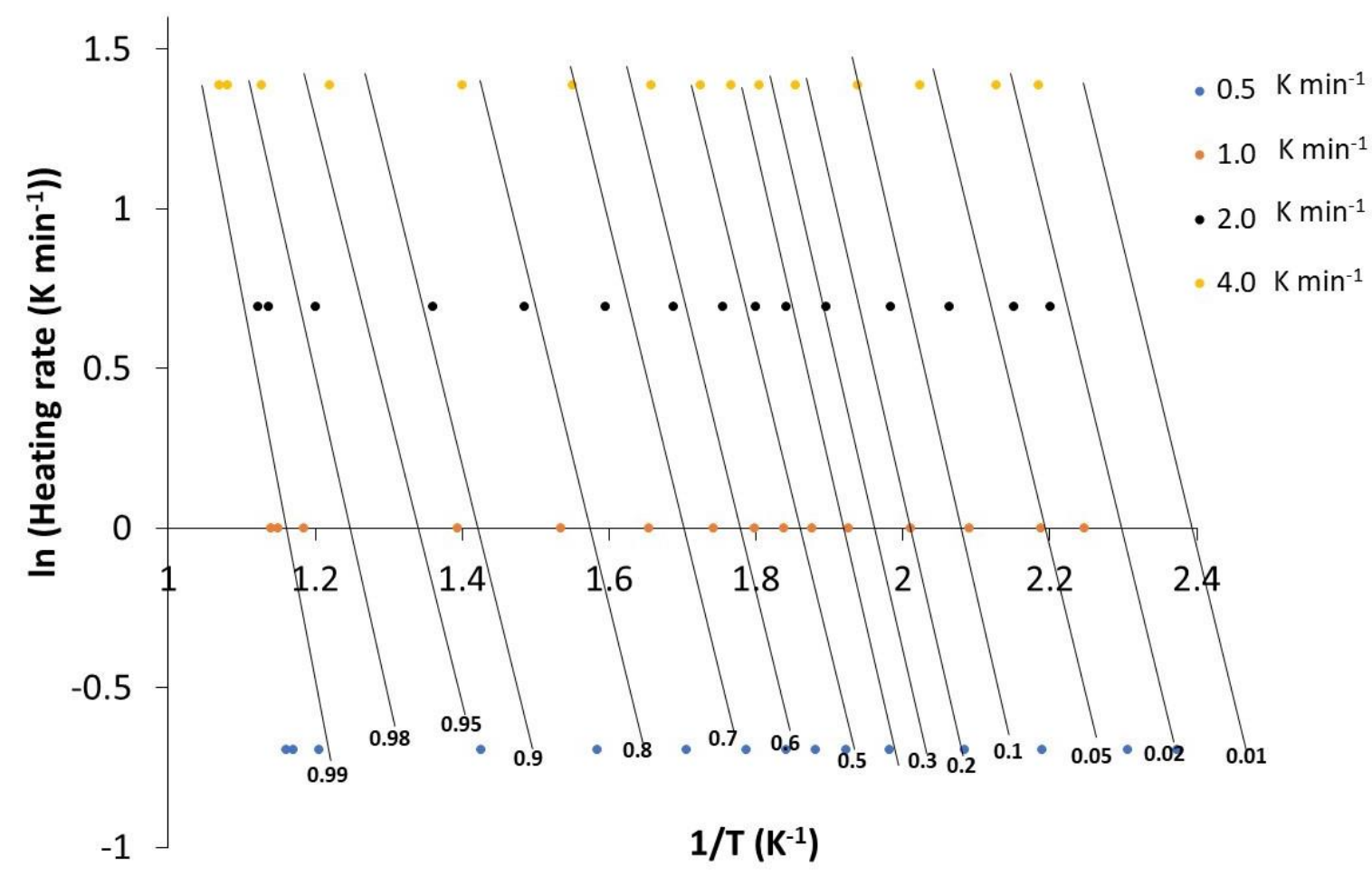

Fig. 9a. Arrhenius plots of SD using Ozawa-Flynn-Wall [4] method

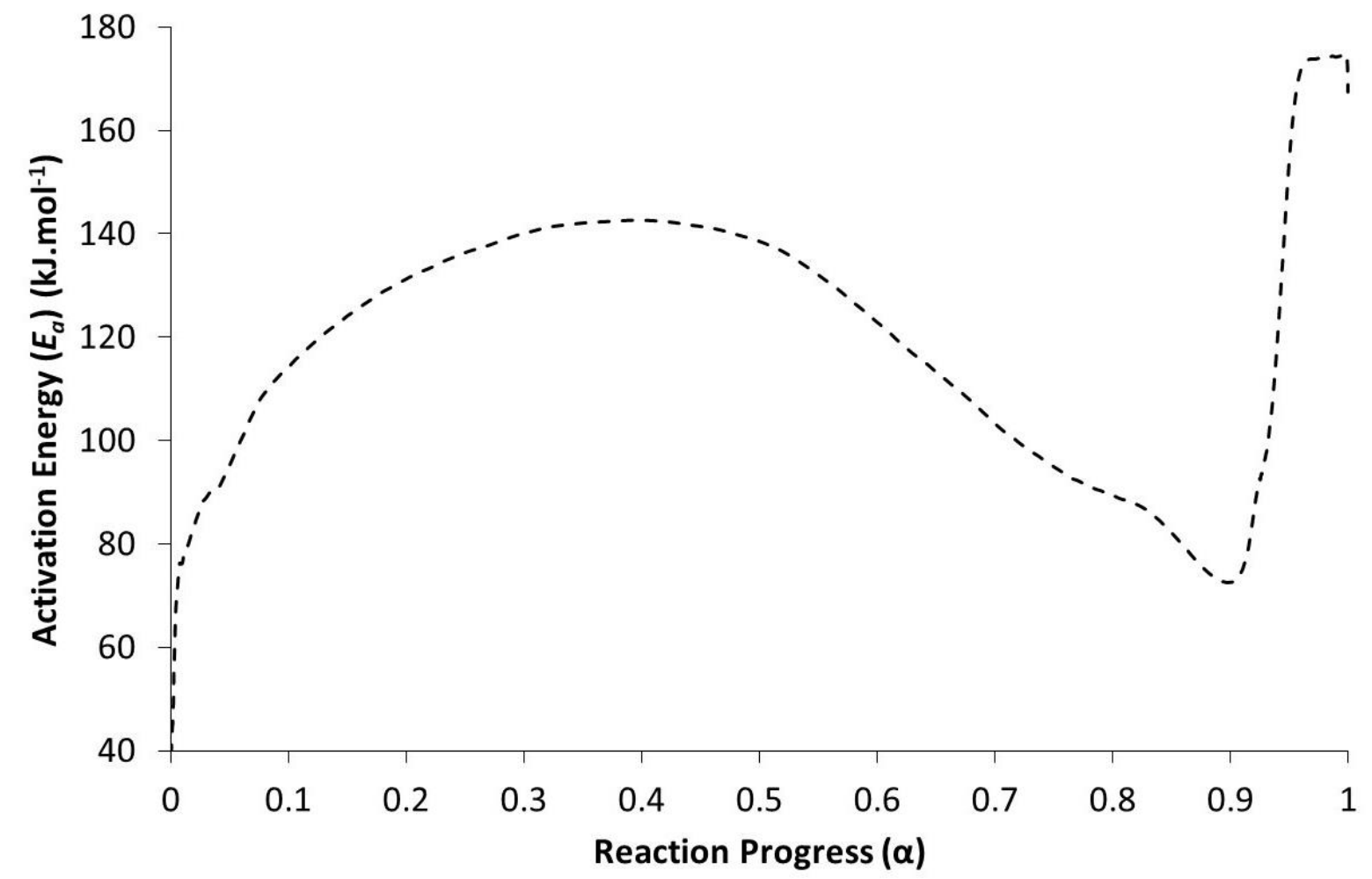

Fig. 9b. The activation energy $\left(E_{a}\right)$ calculated by the Ozawa-Flynn-Wall [4] method 


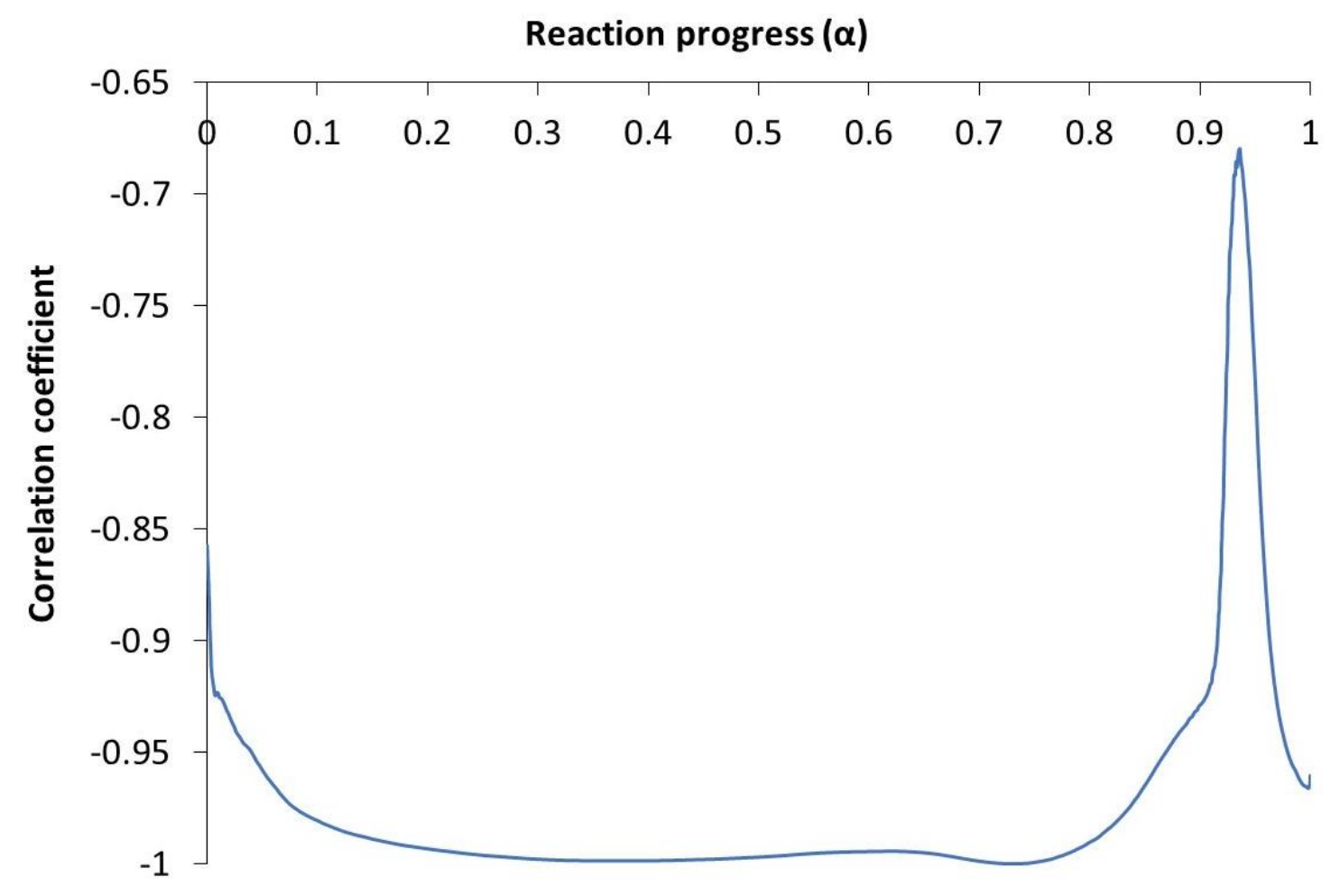

Fig. 9c. The correlation coefficient of the activation energy determined by the Ozawa-Flynn-Wall [4] method

\subsubsection{Comparison of Results with Literature}

The activation energy reported in this work from ASTM-E698, Ozawa-Flynn-Wall and differential iso-conversional are 169.8, $75-175$ and $85-190 \mathrm{~kJ} \mathrm{~mol}^{-1}$, respectively. These values agree with reports from other authors, as compared in Table 3.

For instance, Alvarez et al. [98] reported that the differential iso-conversional method is a more appropriate method to determine the kinetic parameters as it observes differences in the trend of the $E_{a}$ and $k_{0}$ as a function of the reaction. Cai et al. [99] and Navarro et al. [100] also explain the activation energy required for the pyrolysis of biomass. Bartocci et al. [58] reported activation energy of solid digestate from energy crop with values as $99-204.1 \mathrm{~kJ} \mathrm{~mol}^{-1}$; Zhang et al. [55] reported activation energy of corn stover digestate with values as $99-331 \mathrm{~kJ} \mathrm{~mol}^{-}$ 1; Osman et al. [4] examined activation energy for miscanthus and reported that it was between 
$40-165 \mathrm{~kJ} \mathrm{~mol}^{-1}$; Jayaraman et al. [101] investigated activation energy for poplar wood, hazelnut shell, and wheat bran with values reported as $66.80-68.56,83.73-93.25$, and $162.17-167.4 \mathrm{~kJ} \mathrm{~mol}^{-1}$ respectively. Munir et al. [22] stated that the activation energy of cotton stalk, shea meal, and sugar cane was between $108-116 \mathrm{~kJ} \mathrm{~mol}^{-1}$, while Cortes and Bridgwater [102] reported activation energy for the same biomass in the range of $129-156$ $\mathrm{kJ} \mathrm{mol}^{-1}$. Kok and Ozgur [103] used Ozawa-Flynn-Wall method for hazelnut shell and it was reported that the activation energy was $83.8 \mathrm{~kJ} \mathrm{~mol}^{-1}$.

Table 3. Activation energy of different biomass feedstocks using different kinetic models

\begin{tabular}{|l|c|c|c|}
\hline \multicolumn{1}{|c|}{ METHOD USED } & FEEDSTOCK & $\begin{array}{c}\text { ACTIVATION ENERGY } \\
\left(\mathbf{k J ~ m o l}^{-1} \mathbf{)}\right.\end{array}$ & Reference \\
\hline Differential-Iso Conversional & Digestate & $85-190.0$ & This Work \\
\hline ASTM-E698 & Digestate & 169.8 & This Work \\
Ozawa-Flynn-Wall & Digestate & $75-175.0$ & This Work \\
Isoconversional & Sawdust & 170.1 & {$[18]$} \\
\hline Starink model-free & Digestate & $99-204.1$ & {$[58]$} \\
\hline Distributed activation energy model & Digestate & $99-331.0$ & {$[55]$} \\
Ozawa-Flynn-Wall & Miscanthus & $40-165.0$ & {$[4]$} \\
\hline Ozawa-Flynn-Wall & Popular Wood & $66.8-68.6$ & {$[98]$} \\
\hline Ozawa-Flynn-Wall & Hazelnut Shell & $83.73-93.3$ & {$[98]$} \\
\hline Ozawa-Flynn-Wall & Wheat Bran & $162.17-167.4$ & {$[98]$} \\
\hline Non-isothermal and Ozawa-Flynn-Wall & Shea Meal & $108-116.0$ & {$[22]$} \\
\hline
\end{tabular}

\subsection{Isothermal prediction of the SD pyrolysis}


The kinetic prediction of SD isothermal pyrolysis reaction progress is possible by the AKTS software when the temperature dependence is derived from the different heating ramp rates. As can be seen in Fig. 10, the prediction suggests that decomposition of the sample requires a temperature greater than $210^{\circ} \mathrm{C}$ to commence. It is also predicted that only $20 \%(\alpha=0.2)$ of the SD sample decomposes after a quarter of an hour at $435{ }^{\circ} \mathrm{C}$. At an increased temperature of $615^{\circ} \mathrm{C}, 70 \%(\alpha=0.7)$ decomposes within the same time period. It is predicted as indicated from the plot that at $660^{\circ} \mathrm{C}$, maximum conversion is eventually achieved, beginning at $\alpha=0.8$ at $\sim 30 \mathrm{~s}$ and approaching $\alpha=1.0$ by $\sim 15 \mathrm{~min}$. Additionally, it is worth noting that at above $345^{\circ} \mathrm{C}$ diminishing returns begin to arise in the pyrolysis of SD. For instance, a step change of $45{ }^{\circ} \mathrm{C}$ yields a higher rise in reaction progress at lower temperatures. However, above this temperature of $345^{\circ} \mathrm{C}$, there is a smaller change in reaction progress when considering higher temperatures. An example of this can be seen at 14 minutes, where below this temperature $\left(300^{\circ} \mathrm{C}\right)$, the reaction progress was seen to be 0.56 . Whereas at $345^{\circ} \mathrm{C}$, it is measured at 0.69 . This means that the alpha value changed by 0.13 over this $45^{\circ} \mathrm{C}$ gap. However, the reaction progress at $390{ }^{\circ} \mathrm{C}$ was shown to be 0.76 and therefore the alpha value only varied by 0.07 in this $45^{\circ} \mathrm{C}$ change. Ultimately the implications of this are that diminishing returns will exist in the pyrolysis of SD and it is, therefore, recommended that if isothermal pyrolysis was to occur, the reaction should be carried out in this range. As there is negligible difference in $615^{\circ} \mathrm{C}$ and $660^{\circ} \mathrm{C}$, it is also recommended that the reaction should be conducted at $615^{\circ} \mathrm{C}$ to yield positive benefits in terms of reaction time. 


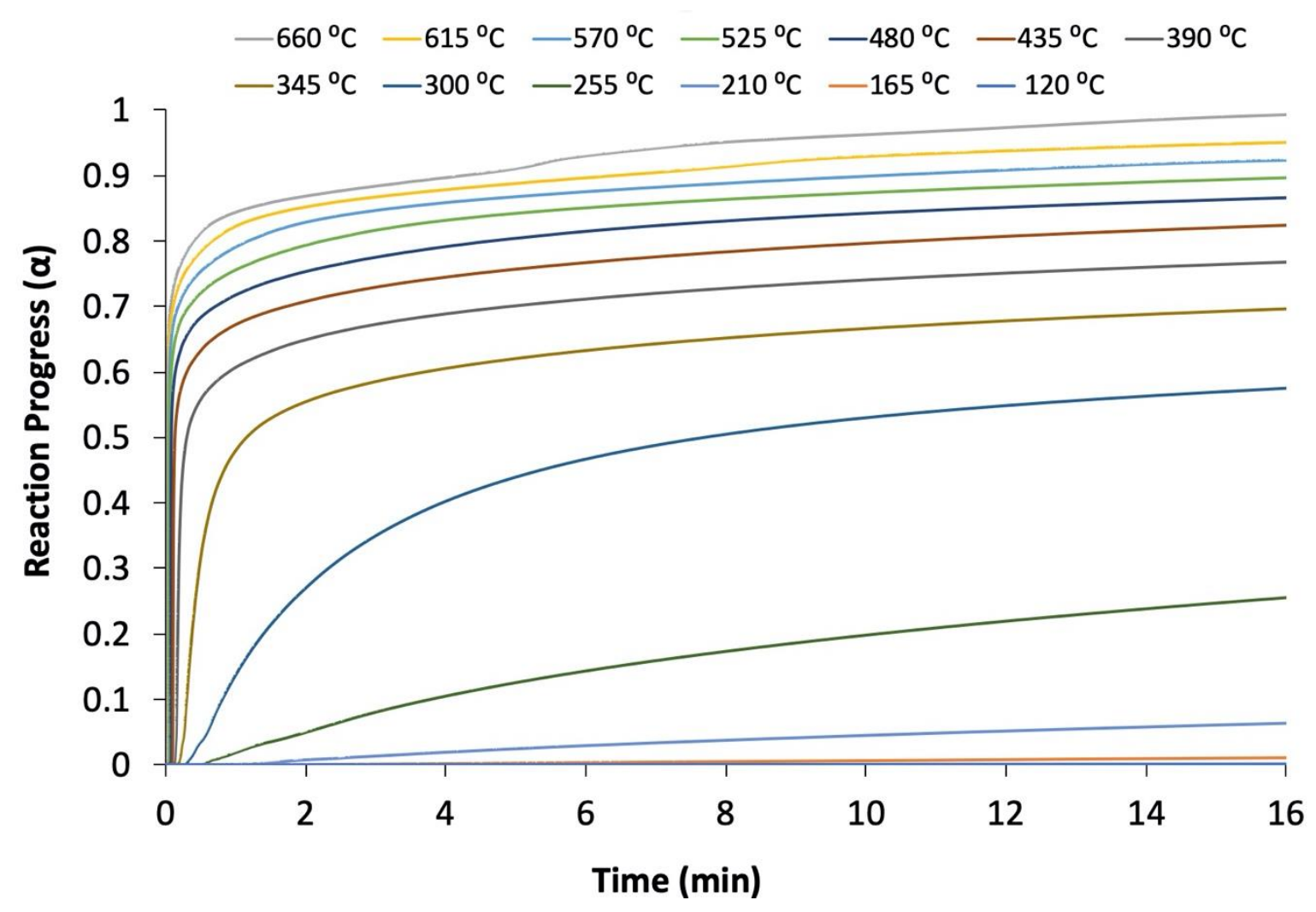

Fig. 10. Kinetic isothermal prediction of solid digestate pyrolysis using AKTS software

The calculated activation energy of SD is relatively high, hence the relatively high temperature of $210^{\circ} \mathrm{C}$ required for the onset decomposition. Although hemicellulose is typically completely converted by $180^{\circ} \mathrm{C}$ [104], the onset decomposition temperature of $210^{\circ} \mathrm{C}$ is not unexpected since it is reported that decomposition of cellulose and lignin initiates at $210^{\circ} \mathrm{C}[105]$ and $\sim 200$ ${ }^{\circ} \mathrm{C}$ [106], respectively. This also accounts for the $\mathrm{HHV}\left(11.72 \mathrm{~kJ} \mathrm{~kg}^{-1}\right)$ and LHV $\left(9.90 \mathrm{~kJ} \mathrm{~kg}^{-1}\right)$ for SD being lower than that of other biomass; for instance the HHV for miscanthus (16.58 kJ $\left.\mathrm{kg}^{-1}\right)$ and bagasse $\left(17.30 \mathrm{~kJ} \mathrm{~kg}^{-1}\right)[62,107]$. Nevertheless, these values still show that SD is combustible and has a significant energy potential.

Blades et al. [61] investigated the potential of a circular economy at a $500 \mathrm{~kW}$ standalone onfarm AD plant. This AD plant produces 102429 MJ per day of biogas from a combination of three feedstocks (grass silage, chicken litter and cattle slurry at 20.5, 8.5 and 13.7 tonnes per day, respectively). This biogas production was found to generate $\sim 66 \mathrm{~kg}$ of solid digestate per tonne of feedstock [108]. As such, based on the lower heating value, this would indicate 
the potential of pyrolysis of SD to produce an additional $653.4 \mathrm{~kJ}$ per tonne of feedstock, meaning a potential increase of at least $27.9 \mathrm{MJ}$ energy production per day. Furthermore, the post pyrolytic char will have become even more concentrated in metals, such as potassium, which means that this char can become a viable feedstock for the fertiliser industry, as has been previously suggested [4]. This understanding aids the concept of a circular economy for anaerobic digestion and the energy potential of SD, thereby making AD plants more profitable.

\subsection{CONCLUSIONS}

In this study the physiochemical pyrolysis properties of SD from AD were analysed and the resultant char to assess the potential valorisation of the residual SD. AKTS software was used to calculate the activation energy $\left(E_{a}=85-190 \mathrm{~kJ} \mathrm{~mol}^{-1}\right)$ and pre-exponential factor $\left(k_{0}=-4\right.$ $-23 \mathrm{~s}^{-1}$ ) kinetic parameters for the pyrolysis of SD using the differential iso-conversional model. The calculated parameters were compared with results from alternative models (the Ozawa-Flynn-Wall and the ASTM-E698). Furthermore, the calculated kinetic parameters were used to generate simulations for the reaction progress and reaction rate. A high correlation was observed with the comparison between these simulations and the experimental data, highlighting the accuracy of the calculated kinetic parameters. The kinetic predictions from the AKTS software for the isothermal pyrolysis of SD indicated that a temperature higher than 210 ${ }^{\circ} \mathrm{C}$ is required for the onset of decomposition of the SD sample. From the prediction, it shows that at above $345{ }^{\circ} \mathrm{C}$ diminishing returns begin to arise in the pyrolysis of $\mathrm{SD}$ and implies that diminishing returns will exist in the pyrolysis of SD. It is, therefore, recommended that if isothermal pyrolysis was to occur, the reaction should be carried out in this range. As there is negligible difference in $615^{\circ} \mathrm{C}$ and $660^{\circ} \mathrm{C}$, it is also recommended that the reaction should be conducted at maximum $615^{\circ} \mathrm{C}$ to yield positive benefits in terms of reaction time. Importantly, calculations of the thermokinetics data have indicated the potential for an increase of $27.9 \mathrm{MJ}$ per day for a $500 \mathrm{~kW}$ AD plant. This information demonstrates the energy potential of SD and 
so will aid the concept of a circular economy for AD plants while also contributing to UN SDG no. 7 (clean and affordable energy) and no. 12 (responsible consumption and production). In consideration of future work, greater mechanistic insights for the pyrolysis of SD are still required while it is expected that the kinetics and reaction parameters recommendations from this work will aid the design of reactor systems for pyrolysis of biomass substrate at any scale.

\section{ACKNOWLEDGMENTS}

The authors would like to acknowledge The Bryden Centre and Renewable Engine for funding. The Bryden Centre (Project ID VA5048) and Renewable Engine (Project ID VA5033) projects are both supported by the European Union's INTERREG VA Programme, managed by the Special EU Programmes Body (SEUPB) with match funding provided by the Department for the Economy in Northern Ireland and the Department of Business, Enterprise and Innovation in the Republic of Ireland.

The authors would like to thank Dr Mark Russell of School of Natural and Built Environment at Queen's University Belfast for TGA experiments. The continued support of and supply of digestate material from Thomas Cromie (AgriAD) as well as Chris Johnston and Dr Gary Lyons (Agri-food and Biosciences Institute) are also greatly appreciated.

Disclaimer: The views and opinions expressed in this paper do not necessarily reflect those of the European Commission or the Special EU Programmes Body (SEUPB). 


\section{NOTATION}

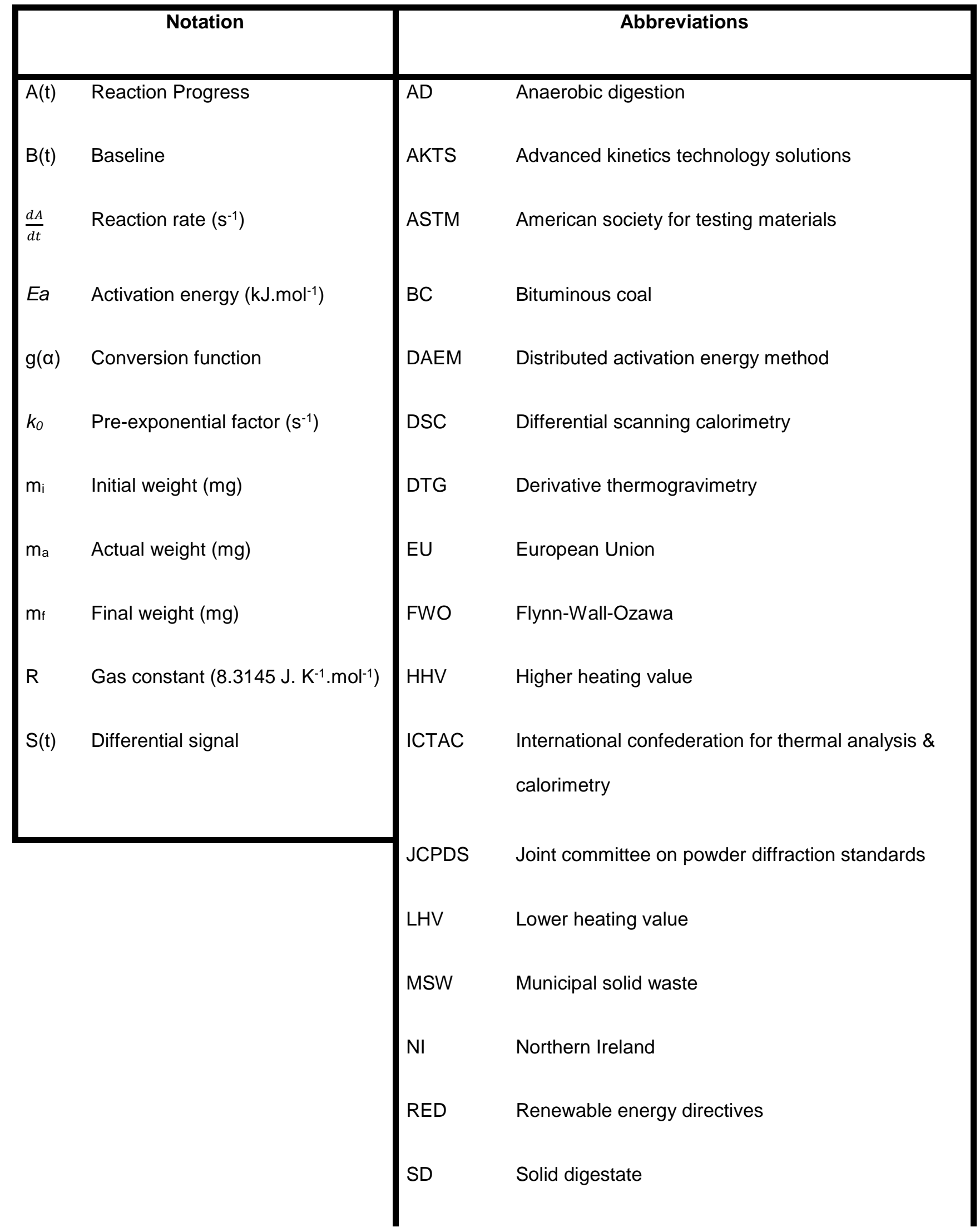


SS

Sewage sludge

TGA Thermogravimetric analysis

UK United Kingdom

UNSDGs United Nations sustainable development goals

WWTP Wastewater treatment plant 


\section{REFERENCES}

[1] M.V. Galkin, J.S. Samec, Lignin Valorization through Catalytic Lignocellulose

Fractionation: A Fundamental Platform for the Future Biorefinery, ChemSusChem:

Chemistry and Sustainability, Energy and Materials 9 (2016) 1544-1558

https://doi.org/10.1002/cssc.201600237

[2] A.I. Osman, A. Abdelkader, C. Farrell, D. Rooney, K. Morgan, Reusing, recycling and upcycling of biomass: A review of practical and kinetic modelling approaches, Fuel Processing Technology 192 (2019) 179-202.https://doi.org/10.1016/j.fuproc.2019.04.026

[3] H. Chen, A.I. Osman, C. Mangwandi, D. Rooney, Upcycling food waste digestate for energy and heavy metal remediation applications, Resources, Conservation \& Recycling: X 3 (2019) 100015.https://doi.org/10.1016/..rcrx.2019.100015

[4] A.I. Osman, A. Abdelkader, C.R. Johnston, K. Morgan, D.W. Rooney, Thermal Investigation and Kinetic Modeling of Lignocellulosic Biomass Combustion for Energy Production and Other Applications, Industrial \& Engineering Chemistry Research 56 (2017) 12119-12130.10.1021/acs.iecr.7b03478

[5] I. Sezer, Thermodynamic, performance and emission investigation of a diesel engine running on dimethyl ether and diethyl ether, International Journal of Thermal Sciences 50 (2011) 1594-1603 https://doi.org/10.1016/j.jthermalsci.2011.03.021

[6] I.U. Hai, F. Sher, G. Zarren, H. Liu, Experimental investigation of tar arresting techniques and their evaluation for product syngas cleaning from bubbling fluidized bed gasifier, Journal of Cleaner Production 240 (2019) 118239 https://doi.org/10.1016/j.jclepro.2019.118239 [7] L. Razzaq, M. Farooq, M. Mujtaba, F. Sher, M. Farhan, M.T. Hassan, M.E.M. Soudagar, A. Atabani, M. Kalam, M. Imran, Modeling Viscosity and Density of Ethanol-Diesel-Biodiesel Ternary Blends for Sustainable Environment, Sustainability 12 (2020) 5186 https://www.mdpi.com/2071-1050/12/12/5186

[8] O. Al-Juboori, F. Sher, U. KHALID, M.b. Niazi, G.Z. Chen, Electrochemical production of sustainable hydrocarbon fuels from CO2 co-electrolysis in eutectic molten melts, ACS 
Sustainable Chemistry \& Engineering (2020)

https://doi.org/10.1021/acssuschemeng.0c03314

[9] F. Biermann, N. Kanie, R.E. Kim, Global governance by goal-setting: the novel approach of the UN Sustainable Development Goals, Current Opinion in Environmental Sustainability 26 (2017) 26-31 https://doi.org/10.1016/j.cosust.2017.01.010

[10] United Nations Sustainable Development Goals, 2015, http://www.un.org/sustainabledevelopment/news/communications-material/ [11] K. Morgan, D.W. Rooney, J. Harrison, R. Coulter, Assessment of the energy recovery potential of waste photovoltaic (pV) modules, (2019) https://doi.org/10.1038/s41598-019$41762-5$

[12] C. Farrell, A. Osman, R. Doherty, M. Saad, X. Zhang, A. Murphy, J. Harrison, A. Vennard, V. Kumaravel, A. Al-Muhtaseb, Technical challenges and opportunities in realising a circular economy for waste photovoltaic modules, Renewable and Sustainable Energy Reviews 128 (2020) 109911 https://doi.org/10.1016/j.rser.2020.109911

[13] G. Koçar, N. Civaş, An overview of biofuels from energy crops: current status and future prospects, Renewable and Sustainable Energy Reviews 28 (2013) 900-916 https://doi.org/10.1016/j.rser.2013.08.022

[14] M. Guo, J.-C. Bi, Characteristics and application of co-pyrolysis of coal/biomass blends with solid heat carrier, Fuel Processing Technology 138 (2015) 743-749 https://doi.org/10.1016/j.fuproc.2015.07.018

[15] A. Franco, N. Giannini, Perspectives for the use of biomass as fuel in combined cycle power plants, International journal of thermal sciences 44 (2005) 163-177 https://doi.org/10.1016/j.ijthermalsci.2004.07.005 [16] A.H. Mahmoudi, F. Hoffmann, B. Peters, Application of XDEM as a novel approach to predict drying of a packed bed, International Journal of Thermal Sciences 75 (2014) 65-75 https://doi.org/10.1016/j.ijthermalsci.2013.07.016

[17] D. Peters, Raw materials, in: R. Ulber, D. Sell (Eds.) White Biotechnology, Springer, Berlin, 2006, pp. 1-30. 
[18] F. Sher, S.Z. Iqbal, H. Liu, M. Imran, C.E. Snape, Thermal and kinetic analysis of diverse biomass fuels under different reaction environment: A way forward to renewable energy sources, Energy Conversion and Management 203 (2020) 112266 DOI: 10.1016/j.enconman.2019.112266

[19] R.K. Mishra, K. Mohanty, Pyrolysis kinetics and thermal behavior of waste sawdust biomass using thermogravimetric analysis, Bioresource technology 251 (2018) 63-74 https://doi.org/10.1016/j.biortech.2017.12.029

[20] D. Mulenga, S. Siziya, Indoor air pollution related respiratory ill health, a sequel of biomass use, SciMedicine Journal 1 (2019) 30-37 https://doi.org/10.28991/SciMedJ-2019$0101-5$

[21] I.U. Hai, F. Sher, A. Yaqoob, H. Liu, Assessment of biomass energy potential for SRC willow woodchips in a pilot scale bubbling fluidized bed gasifier, Fuel 258 (2019) 116143 https://doi.org/10.1016/j.fuel.2019.116143

[22] S. Munir, S.S. Daood, W. Nimmo, A.M. Cunliffe, B.M. Gibbs, Thermal analysis and devolatilization kinetics of cotton stalk, sugar cane bagasse and shea meal under nitrogen and air atmospheres, Bioresour Technol 100 (2009) 1413-

1418.10.1016/j.biortech.2008.07.065

[23] P. McKendry, Energy production from biomass (part 2): conversion technologies, Bioresource Technology 83 (2002) 47-54.http://dx.doi.org/10.1016/S0960-8524(01)00119-5 [24] J. Baruah, B.K. Nath, R. Sharma, S. Kumar, R.C. Deka, D.C. Baruah, E. Kalita, Recent trends in the pretreatment of lignocellulosic biomass for value-added products, Frontiers in Energy Research 6 (2018) 141 https://doi.org/10.3389/fenrg.2018.00141 [25] P. McKendry, Energy production from biomass (part 1): overview of biomass, Bioresource technology 83 (2002) 37-46 DOI: 10.1016/S0960-8524(01)00118-3 [26] J.J. Cheng, G.R. Timilsina, Status and barriers of advanced biofuel technologies: A review, Renewable Energy 36 (2011) 35413549.http://dx.doi.org/10.1016/j.renene.2011.04.031 
[27] C.N. Arenas, M.V. Navarro, J.D. Martínez, Pyrolysis kinetics of biomass wastes using isoconversional methods and the distributed activation energy model, Bioresource technology 288 (2019) 121485 https://doi.org/10.1016/j.biortech.2019.121485 [28] K. Jayaraman, I. Gökalp, Pyrolysis, combustion and gasification characteristics of miscanthus and sewage sludge, Energy Conversion and Management 89 (2015) 83-91 DOI: $\underline{10.1016 / j . e n c o n m a n .2014 .09 .058 ~}$

[29] F.R. Amin, H. Khalid, H. Zhang, S.U. Rahman, G. Liu, C. Chen, R. Zhang, Pretreatment methods of lignocellulosic biomass for anaerobic digestion, 2017, DOI 10.1186/s13568-0170375-4

[30] L. De Baere, Will anaerobic digestion of solid waste survive in the future?, Water Science and Technology 53 (2006) 187-194 https://doi.org/10.2166/wst.2006.249 [31] I. Angelidaki, B.K. Ahring, Thermophilic anaerobic digestion of livestock waste: the effect of ammonia, Applied Microbiology and Biotechnology 38 (1993) 560-564 https://doi.org/10.1007/BF00242955

[32] M. Carmona-Cabello, I.L. Garcia, D. Leiva-Candia, M.P. Dorado, Valorization of food waste based on its composition through the concept of biorefinery, Current Opinion in Green and Sustainable Chemistry 14 (2018) 67-79 DOI: $\underline{10.1016 / \text {..cogsc.2018.06.011 }}$ [33] J. Edwards, M. Othman, S. Burn, A review of policy drivers and barriers for the use of anaerobic digestion in Europe, the United States and Australia, Renewable and Sustainable Energy Reviews 52 (2015) 815-828 DOI: 10.1016/j.rser.2015.07.112

[34] EA, Waste Protocols Project-Blast Furnace Slag, Environment Agency UK, 2007, [35] H. Spliethoff, K.R.G. Hein, Effect of co-combustion of biomass on emissions in pulverized fuel furnaces, Fuel Processing Technology 54 (1998) 189-205 DOI: $10.1016 / \mathrm{S} 0378-3820(97) 00069-6$ [36] E. Maranon, L. Castrillon, G. Quiroga, Y. Fernandez-Nava, L. Gomez, M.M. Garcia, Codigestion of cattle manure with food waste and sludge to increase biogas production, Waste Manag 32 (2012) 1821-1825.10.1016/j.wasman.2012.05.033 
[37] H.-W. Kim, S.-K. Han, H.-S. Shin, Anaerobic co-digestion of sewage sludge and food waste using temperature-phased anaerobic digestion process, Water science and technology 50 (2004) 107-114 https://doi.org/10.2166/wst.2004.0547 [38] U.E.P. Agency, National Overview: Facts and Figures on Materials, Wastes and Recycling, (2019)

[39] F. Monlau, C. Sambusiti, E. Ficara, A. Aboulkas, A. Barakat, H. Carrere, New opportunities for agricultural digestate valorization: current situation and perspectives, Energy \& Environmental Science 8 (2015) 2600-2621 https://doi.org/10.1039/C5EE01633A [40] M. Ayoub, I.G.A.-A. Rashed, A. El-Morsy, Energy Production from Sewage Sludge in a Proposed Wastewater Treatment Plant, Civil Engineering Journal 2 (2016) 637-645 https://doi.org/10.28991/cej-2016-00000064

[41] M. Buaisha, S. Balku, Ş.Ö. Yaman, Heavy Metal Removal Investigation in Conventional Activated Sludge Systems, Civil Engineering Journal 6 (2020) 470-477 https://doi.org/10.28991/cej-2020-03091484 [42] I. Obernberger, Decentralized biomass combustion: state of the art and future development1, Biomass and Bioenergy 14 (1998) 33-56 https://doi.org/10.1016/S09619534(97)00034-2

[43] E. Parliament, DIRECTIVE (EU) 2018/844 OF THE EUROPEAN PARLIAMENT AND OF THE COUNCIL of 30 May 2018 amending Directive 2010/31/EU on the energy performance of buildings and Directive 2012/27/EU on energy efficiency [Internet]. 2018, http://data.europa.eu/eli/dir/2018/844/oj

[44] M. Moretti, M. Van Dael, R. Malina, S. Van Passel, Environmental assessment of waste feedstock mono-dimensional and bio-refinery systems: Combining manure co-digestion and municipal waste anaerobic digestion, Journal of cleaner production 171 (2018) 954-961 https://doi.org/10.1016/j.jclepro.2017.10.097

[45] M. Fernandez-Lopez, M. Puig-Gamero, D. Lopez-Gonzalez, A. Avalos-Ramirez, J. Valverde, L. Sanchez-Silva, Life cycle assessment of swine and dairy manure: pyrolysis and 
combustion processes, Bioresour Technol 182 (2015) 184-

192.10.1016/j.biortech.2015.01.140

[46] E.A.B. da Silva, M. Zabkova, J.D. Araújo, C.A. Cateto, M.F. Barreiro, M.N. Belgacem, A.E. Rodrigues, An integrated process to produce vanillin and lignin-based polyurethanes from Kraft lignin, Chemical Engineering Research and Design 87 (2009) 1276-1292 https://doi.org/10.1016/j.cherd.2009.05.008

[47] J. Zakzeski, P.C. Bruijnincx, A.L. Jongerius, B.M. Weckhuysen, The catalytic valorization of lignin for the production of renewable chemicals, Chemical reviews 110 (2010) 3552-3599 https://doi.org/10.1021/cr900354u

[48] N. Scarlat, J.-F. Dallemand, F. Monforti-Ferrario, M. Banja, V. Motola, Renewable energy policy framework and bioenergy contribution in the European Union-An overview from National Renewable Energy Action Plans and Progress Reports, Renewable and Sustainable Energy Reviews 51 (2015) 969-985 https://doi.org/10.1016/j.rser.2015.06.062 [49] M. Banja, R. Sikkema, M. Jégard, V. Motola, J.-F. Dallemand, Biomass for energy in the EU-The support framework, Energy policy 131 (2019) 215-228 https://doi.org/10.1016/j.enpol.2019.04.038

[50] Y. Huang, M. Chen, Y. Li, An innovative evaluation method for kinetic parameters in distributed activation energy model and its application in thermochemical process of solid fuels, Thermochimica Acta 655 (2017) 42-51 https://doi.org/10.1016/j.tca.2017.06.009 [51] Q. He, L. Ding, Y. Gong, W. Li, J. Wei, G. Yu, Effect of torrefaction on pinewood pyrolysis kinetics and thermal behavior using thermogravimetric analysis, Bioresource technology 280 (2019) 104-111 https://doi.org/10.1016/j.biortech.2019.01.138 [52] S. Vyazovkin, C.A. Wight, Model-free and model-fitting approaches to kinetic analysis of isothermal and nonisothermal data, Thermochimica acta 340 (1999) 53-68 https://doi.org/10.1016/S0040-6031(99)00253-1

[53] S. Scott, J. Dennis, J. Davidson, A. Hayhurst, An algorithm for determining the kinetics of devolatilisation of complex solid fuels from thermogravimetric experiments, Chemical engineering science 61 (2006) 2339-2348 https://doi.org/10.1016/j.ces.2005.11.002 
[54] G. Várhegyi, P. Szabó, M.J. Antal, Kinetics of charcoal devolatilization, Energy \& fuels 16 (2002) 724-731 https://doi.org/10.1021/ef010227v

[55] D. Zhang, F. Wang, W. Yi, Z. Li, X. Shen, W. Niu, Comparison study on pyrolysis characteristics and kinetics of corn stover and its digestate by TG-FTIR, BioResources 12 (2017) 8240-8254 DOI: 10.15376/biores.12.4.8240-8254

[56] K. Perera, M. Narayana, Kissinger method: the sequential approach and DAEM for kinetic study of rubber and gliricidia wood, Journal of the National Science Foundation of Sri Lanka 46 (2018) 187-196 DOI: http://dx.doi.org/10.4038/jnsfsr.v46i2.8419

[57] M. Kumar, P. Mishra, S. Upadhyay, Thermal degradation of rice husk: Effect of pretreatment on kinetic and thermodynamic parameters, Fuel 268 (2020) 117164 https://doi.org/10.1016/j.fuel.2020.117164

[58] P. Bartocci, R. Tschentscher, R.E. Stensrod, M. Barbanera, F. Fantozzi, Kinetic Analysis of Digestate Slow Pyrolysis with the Application of the Master-Plots Method and Independent Parallel Reactions Scheme, Molecules 24 (2019) 1657.10.3390/molecules24091657 https://doi.org/10.3390/molecules24091657 [59] R.C. Pettersen, The chemical composition of wood, ACS Publications 1984. DOI: 10.1021/ba-1984-0207.ch002

[60] O. Adeeyo, O.M. Oresegun, T.E. Oladimeji, Compositional analysis of lignocellulosic materials: Evaluation of an economically viable method suitable for woody and non-woody biomass, American Journal of Engineering Research (AJER) 4 (2015) 14-19 http://eprints.covenantuniversity.edu.ng/id/eprint/5715

[61] L. Blades, K. Morgan, R. Douglas, S. Glover, M. De Rosa, T. Cromie, B. Smyth, Circular biogas-based economy in a rural agricultural setting, Energy Procedia 123 (2017) 89-96 https://doi.org/10.1016/j.egypro.2017.07.255

[62] A.I. Osman, A.T. Ahmed, C.R. Johnston, D.W. Rooney, Physicochemical characterization of miscanthus and its application in heavy metals removal from wastewaters, Environmental Progress \& Sustainable Energy 37 (2018) 10581067.10.1002/ep.12783 
[63] A. International, Standard test method for compositional analysis by thermogravimetry, ASTM International2003.

[64] Advance Kinetic Technology Solutions, Setaram KEP Technologies, Switzerland, 2016, [65] S. Chen, D. Gao, X. Yu, Y. Guo, T. Deng, Thermokinetics of lithium extraction with the novel extraction systems (tri-isobutyl phosphate+ ionic liquid+ kerosene), The Journal of Chemical Thermodynamics 123 (2018) 79-85 https://doi.org/10.1016/j.jct.2018.03.026 [66] W. Shi, A. Chen, H. Zeng, Application of thermal kinetics software in aging of energetic materials, Chemical Propellants \& Polymeric Materials (2010) 20

[67] S. Vyazovkin, A.K. Burnham, J.M. Criado, L.A. Pérez-Maqueda, C. Popescu, N. Sbirrazzuoli, ICTAC Kinetics Committee recommendations for performing kinetic computations on thermal analysis data, Thermochimica acta 520 (2011) 1-19 https://doi.org/10.1016/j.tca.2011.03.034

[68] P. Zou, S. Tang, Z. Fu, H. Xiong, Isothermal and non-isothermal crystallization kinetics of modified rape straw flour/high-density polyethylene composites, International Journal of Thermal Sciences 48 (2009) 837-846 https://doi.org/10.1016/j.ijthermalsci.2008.06.010 [69] A.K. Burnham, Computational aspects of kinetic analysis.: Part D: The ICTAC kinetics project-multi-thermal-history model-fitting methods and their relation to isoconversional methods, Thermochimica Acta 355 (2000) 165-170 https://doi.org/10.1016/S0040$6031(00) 00446-9$

[70] F. Carrasco, P. Pages, Kinetics of the thermal decomposition of green alga ulva by thermogravimetry, Journal of applied polymer science 93 (2004) 1913-1922 https://doi.org/10.1002/app.20675

[71] A. Iliyas, K. Hawboldt, F. Khan, Thermal stability investigation of sulfide minerals in DSC, Journal of hazardous materials 178 (2010) 814-822 https://doi.org/10.1016/j.jhazmat.2010.01.149 [72] J. Touitou, F. Aiouache, R. Burch, R. Douglas, C. Hardacre, K. Morgan, J. Sá, C. Stewart, J. Stewart, A. Goguet, Evaluation of an in situ spatial resolution instrument for fixed beds through the assessment of the invasiveness of probes and a comparison with a micro- 
kinetic model, Journal of catalysis 319 (2014) 239-246

https://doi.org/10.1016/j.jcat.2014.09.006

[73] J. Werther, M. Saenger, E.U. Hartge, T. Ogada, Z. Siagi, Combustion of agricultural residues, Progress in energy and combustion science 26 (2000) 1-27 https://doi.org/10.1016/S0360-1285(99)00005-2

[74] A. Demirbaş, Yields of hydrogen-rich gaseous products via pyrolysis from selected biomass samples, Fuel 80 (2001) 1885-1891 https://doi.org/10.1016/S0016-2361(01)000709

[75] D. Sarkar, Thermal power plant: design and operation, Elsevier2015.

[76] D. Green, R. Lewis, The effects of soot-contaminated engine oil on wear and friction: a review, Proceedings of the Institution of Mechanical Engineers, Part D: Journal of Automobile Engineering 222 (2008) 1669-1689 https://doi.org/10.1243\%2F09544070JAUTO468 [77] F. Tambone, F. Adani, Nitrogen mineralization from digestate in comparison to sewage sludge, compost and urea in a laboratory incubated soil experiment, Journal of Plant Nutrition and Soil Science 180 (2017) 355-365 https://doi.org/10.1002/jpln.201600241 [78] A. Valera-Medina, H. Xiao, M. Owen-Jones, W. David, P. Bowen, Ammonia for power, Progress in Energy and Combustion Science 69 (2018) 63-102 https://doi.org/10.1016/j.pecs.2018.07.001 [79] S. Channiwala, P. Parikh, A unified correlation for estimating HHV of solid, liquid and gaseous fuels, Fuel 81 (2002) 1051-1063 https://doi.org/10.1016/S0016-2361(01)00131-4 [80] A.A. Khan, W. De Jong, P.J. Jansens, H. Spliethoff, Biomass combustion in fluidized bed boilers: Potential problems and remedies, Fuel Processing Technology 90 (2009) 21-50 https://doi.org/10.1016/j.fuproc.2008.07.012

[81] K. Peters, X. Xia, A. Pomerantz, O. Mullins, Geochemistry applied to evaluation of unconventional resources, Unconventional oil and gas resources handbook, Elsevier2016, pp. 71-126. https://doi.org/10.1016/B978-0-12-802238-2.00003-1 
[82] S. Nanda, P. Mohanty, K. Pant, S. Naik, J. Kozinski, A. Dalai, Characterisation of Noth American Lignocellulosic Biomass and Biochars in Terms of their Candidacy for Alternate Renewable Fuels, BioEnergy Research 6 (2012) 663-677 https://doi.org/10.1007/s12155012-9281-4

[83] A.I. Osman, J. Blewitt, J.K. Abu-Dahrieh, C. Farrell, A.a.H. Al-Muhtaseb, J. Harrison, D.W. Rooney, Production and characterisation of activated carbon and carbon nanotubes from potato peel waste and their application in heavy metal removal, Environmental Science and Pollution Research 26 (2019) 37228-37241.10.1007/s11356-019-06594-w

[84] C. Xue, T. Xu, J. Wang, J. Zheng, X. Hao, G. Guan, Direct synthesis of alkaline earth metal Ca incorporated KHSi2O5 layered silicate, Materials Letters 161 (2015) 530533.https://doi.org/10.1016/j.matlet.2015.09.033

[85] A.K. Swain, D. Bahadur, Facile synthesis of twisted graphene solution from graphiteKCl, RSC Advances 3 (2013) 19243-19246.10.1039/C3RA43793K

[86] A.I. Osman, E. O'Connor, G. McSpadden, J.K. Abu-Dahrieh, C. Farrell, A.a.H. AlMuhtaseb, J. Harrison, D.W. Rooney, Upcycling brewer's spent grain waste into activated carbon and carbon nanotubes for energy and other applications via two-stage activation, Journal of Chemical Technology \& Biotechnology 95 (2020) 183-195.10.1002/jctb.6220 [87] J.E. White, W.J. Catallo, B.L. Legendre, Biomass pyrolysis kinetics: a comparative critical review with relevant agricultural residue case studies, Journal of analytical and applied pyrolysis 91 (2011) 1-33 https://doi.org/10.1016/j.jaap.2011.01.004

[88] M. Carrier, A. Loppinet-Serani, D. Denux, J.-M. Lasnier, F. Ham-Pichavant, F. Cansell, C. Aymonier, Thermogravimetric analysis as a new method to determine the lignocellulosic composition of biomass, Biomass and bioenergy 35 (2011) 298-307 https://doi.org/10.1016/j.biombioe.2010.08.067

[89] G. Özsin, A.E. Pütün, Kinetics and evolved gas analysis for pyrolysis of food processing wastes using TGA/MS/FT-IR, Waste Management 64 (2017) 315-326 https://doi.org/10.1016/j.wasman.2017.03.020 
[90] B. Benkoussas, J.-L. Consalvi, B. Porterie, N. Sardoy, J.-C. Loraud, Modelling thermal degradation of woody fuel particles, International Journal of Thermal Sciences 46 (2007) 319-327 https://doi.org/10.1016/j.ijthermalsci.2006.06.016

[91] L. Véchot, I. Bombard, P. Laurent, J. Lieto, Experimental and modelling study of the radiative curing of a polyester-based coating, International Journal of Thermal Sciences 45 (2006) 86-93 https://doi.org/10.1016/j.ijthermalsci.2005.04.004

[92] P.T. Williams, S. Besler, The influence of temperature and heating rate on the slow pyrolysis of biomass, Renewable energy 7 (1996) 233-250 https://doi.org/10.1016/09601481(96)00006-7

[93] C.Z. Zaman, K. Pal, W.A. Yehye, S. Sagadevan, S.T. Shah, G.A. Adebisi, E. Marliana, R.F. Rafique, R.B. Johan, Pyrolysis: A sustainable way to generate energy from waste, Pyrolysis, BoD-Books on Demand2017, pp. 1.

[94] M.A. Islam, M. Auta, G. Kabir, B. Hameed, A thermogravimetric analysis of the combustion kinetics of karanja (Pongamia pinnata) fruit hulls char, Bioresource technology 200 (2016) 335-341 https://doi.org/10.1016/j.biortech.2015.09.057

[95] S. Wang, G. Dai, H. Yang, Z. Luo, Lignocellulosic biomass pyrolysis mechanism: A state-of-the-art review, Progress in Energy and Combustion Science 62 (2017) 3386.10.1016/j.pecs.2017.05.004

[96] G. Henriksson, J. Li, L. Zhang, M.E. Lindström, Lignin utilization, Thermochemical conversion of biomass to liquid fuels and chemicals2010, pp. 222-262.

https://doi.org/10.1039/9781849732260

[97] S. Huang, S. Wu, Y. Wu, J. Gao, The physicochemical properties and catalytic characteristics of different biomass ashes, Energy Sources, Part A: Recovery, Utilization, and Environmental Effects 36 (2014) 402-410 https://doi.org/10.1080/15567036.2012.722746 [98] A. Álvarez, C. Pizarro, R. García, J. Bueno, A. Lavín, Determination of kinetic parameters for biomass combustion, Bioresource technology 216 (2016) 36-43 https://doi.org/10.1016/j.biortech.2016.05.039 
[99] J. Cai, W. Wu, R. Liu, An overview of distributed activation energy model and its application in the pyrolysis of lignocellulosic biomass, Renewable and Sustainable Energy Reviews 36 (2014) 236-246 https://doi.org/10.1016/j.rser.2014.04.052

[100] M.V. Navarro, R. Murillo, A.M. Mastral, N. Puy, J. Bartroli, Application of the distributed activation energy model to biomass and biomass constituents devolatilization, AIChE journal 55 (2009) 2700-2715 https://doi.org/10.1002/aic.11848

[101] K. Jayaraman, M.V. Kok, I. Gokalp, Combustion properties and kinetics of different biomass samples using TG-MS technique, Journal of Thermal Analysis and Calorimetry 127 (2017) 1361-1370 DOI 10.1007/s10973-016-6042-1

[102] A.M. Cortés, A. Bridgwater, Kinetic study of the pyrolysis of miscanthus and its acid hydrolysis residue by thermogravimetric analysis, Fuel Processing Technology 138 (2015) 184-193 https://doi.org/10.1016/j.fuproc.2015.05.013

[103] M.V. Kok, E. Özgür, Thermal analysis and kinetics of biomass samples, Fuel Processing Technology 106 (2013) 739-743 https://doi.org/10.1016/j.fuproc.2012.10.010 [104] M.P. Olszewski, S.A. Nicolae, P.J. Arauzo, M.-M. Titirici, A. Kruse, Wet and dry? Influence of hydrothermal carbonization on the pyrolysis of spent grains, Journal of Cleaner Production (2020) 121101 https://doi.org/10.1016/j.jclepro.2020.121101 [105] M.-M. Titirici, A. Funke, A. Kruse, Hydrothermal carbonization of biomass, Recent advances in Thermo-chemical conversion of biomass, Elsevier2015, pp. 325-352. https://doi.org/10.1016/B978-0-444-63289-0.00012-0 [106] M.A. Islam, M. Asif, B.H. Hameed, Pyrolysis kinetics of raw and hydrothermally carbonized Karanj (Pongamia pinnata) fruit hulls via thermogravimetric analysis, Bioresour Technol 179 (2015) https://doi.org/10.1016/j.biortech.2014.11.115 [107] B. Jenkins, J. Ebeling, Correlation of physical and chemical properties of terrestrial biomass with conversion, (1985) [108] M.N. Pérez-Camacho, R. Curry, Regional assessment of bioeconomy options using the anaerobic biorefinery concept, Proceedings of the Institution of Civil Engineers-Waste 
and Resource Management, Thomas Telford Ltd, 2018, pp. 104-113

https://doi.org/10.1680/jwarm.17.00015 